\title{
Education R and D
}

\author{
Yoshida Rao ${ }^{1}$ \\ IIT Madras, Chennai, India
}

\begin{abstract}
R\&D education is very important even in school level. It also motivates students to focus in studies. Many students want to do application based learning. They don't want to wait to reach a level where the student in him or her is dead. This can be said because the school education system of India is the best, but when it comes to college level, the type of education that is provided kills the student motivation to learn anything new. In college level education is synonymous with passing exams. And when such a student comes to real world where there are not exams, but still student has to learn continuously to face the exam of life. In the exam of life there is no fixed syllabus, no fixed books. To succeed in this type of scenario student has to develop its intiution to find what is relevant for him or her. So our this project focuses on a student right from the school level. We give the student a taste of what it takes to be a researcher. Picking up examples from surroundings like Environmental Chemistry, we teach the student to write and publish a basic research. We tell them how to search the relevant content, we tell them what are the authenticate research websites, how to draw mind maps of the reelvant content, and then write it down using latex and publish it on open source platforms where a student can get doi. This is stage 1 . In stage 2 , a student who has learnt to do basic research can teach other students on the platform. In stage 3 , student can sell his or her research to industry users for money. Being able to monetize one's research at young age, is a good start for entrepreneurship in later life. So the motto is Catch them Young.
\end{abstract}

\footnotetext{
1yoshidarao5@gmail.com https://www.linkingresearchlogic.com/
} 
Keywords: Education Technology, Web Product

\section{Value Proposition}

Value Proposition.

1. Value to Customer

(a) School Students would learn R\&D

(b) Companies could crowdsource these students to do R\&D work

(c) Large number of teachers would get employment in above tasks

2. Customer Problems

(a) Students today want to do more at young age

(b) There is lot of R\&D work available which companies cannot do themselves

(c) Employment is required for large number of people

(d) R\&D work is environment friendly in most cases. So it provides clean employment

3. Services to each customer segment

(a) Students would learn to create and publish scientific content. They would also be paid for it if they are associated with an industry

(b) Industries will get services of young creative minds through crowdsourcing

(c) Teachers will earn by becoming part of this entire process. We will aim at using youngest teachers as possible

4. Customer needs

(a) Students want to make a mark in the world in the youngest possible age

(b) Companies have huge $R \& D$ requirements, which they cannot complete on their own

(c) Teachers get to become part of this process and earn money also 


\section{Customer Relationships}

\section{Customer Relationships.}

1. Customer relationships

(a) Students should be able to put request for a teacher

(b) Student should be able to showcase its work to general public and industry

(c) Industry should be able to get copyrights from student of their work

(d) Teachers should get students, and also a name in the work published by student

(e) Once a student understands the research process, it should be able to become a teacher at the platform

2. Which ones we have established

(a) We have a team for content and course material preparation. This is centered around teaching research methodology. Currently we are focusing on construction technology and infrastructure engineering as these examples are all around us, and students can easily relate to them

(b) We have enlisted one client who requires $\mathrm{R} \& \mathrm{D}$ services for his project. Our motto is to have few clients but those should be able to absorb large amounts of $R \& D$ work. We are hopeful that after seeing our success many more clients would be wanting to list with us, and we would be in a position to choose

3. Integration with model

(a) Ours is an interaction platform, there is no distinction between employees (teachers) and clients (students). Both the customer segments freely interact with each other for self development

(b) Our platform allows industry users to freely go through the work done by students and teachers, and then offer them to sell their work, or to create new work specifically for the industry

4. Costs of customers 
(a) Cost is an online platform

(b) We do not intend to build a new platform at this stage. We are exploring international online platforms which can be used for our purpose. It could be a basic CRM or a platform which allows both chat and video

\section{Channels}

\section{Channels.}

1. Customer channels

(a) There are platforms which have huge learning curve. But these could be advantage to student once it masters it and uses in later professional life. This is also the part of teaching that we want to impart

(b) Advertising is required. We plan to use google ads. Facebook is also useful as the people who are searching for jobs frequently use it with relevant queries

(c) LinkedIn advertising is also considered

2. How are we reaching them now

(a) Currently all the teachers and industry clients we are in contact with we initially found and contacted them on Facebook

(b) Later we are maintaining the contact through LinkedIn and Phone

3. Integration of channels

(a) Our channels are not integrated

(b) We are an open company relying on Facebook pages, LinkedIn and Phone

(c) We plan to integrate all these channels through a CRM platform

4. Which ones are best

(a) Facebook appears to best at this stage

(b) LinkedIn helps in long run

(c) CRM will help in integrating

5. Cost efficient 
(a) All channels are costly

(b) CRM seems to be the cheapest component

6. Customer routines

(a) Those who are in search for jobs, search Facebook daily for it. So a good Facebook ad and page is of help

(b) If one wants to contact experts then LinkedIn is also a good medium

(c) Sending emails from CRM is also useful

\section{Customer segment}

Customer segment.

1. For whom are we creating value

(a) We have no distinction between our clients and customers

(b) We have three categories, Students, Teachers, Industry people

(c) But a student can also play a role of teacher and an industry user

2. Most important customers

100

\section{Key activities}

Key activities.

1. Key activities

(a) A platform is required where students and teachers can work together to create high quality content 
(b) A video calling would be required for students and teachers to come online to discuss the work

(c) Ideal platform would be something like Microsoft Teams, but it is expensive

(d) Project management platforms are also being considered

(e) In first class student would be demonstrated how to publish content and mind maps

(f) Student would then create a fishbone diagram for topic of its interest

(g) Student would then proceed to draw mind map

(h) Next step would be a key variance control worksheet

(i) This would be followed by quality manual

(j) Developing regulations and standards would be next step

(k) Student would then learn to put together a report in latex

125

2. Our distribution channels

(a) An online platform where we can bring teachers and students together 3. Customer relationships

(a) A DIY platform for students and teachers

4. Revenue streams

(a) We will charge students on hourly basis

(b) Students who master the process can become teachers on our platform and can earn money

(c) Industry users can hire students to work for them

\section{Key resources}

135 Key resources.

1. Key resources

(a) An online platform

(b) Marketing on Facebook and others 


\section{Key partners}

140

Key partners.

1. Key partners
(a) Students
(b) Teachers
(c) Industry users
(d) Online platform development and maintenance
(e) CRM providers

2. Key suppliers
(a) Online platform development and maintenance
(b) CRM maintenance

3. Activities of partners

(a) Teachers and students enroll on the platform

(b) Online platform development and maintenance

(c) Customer relationship management through CRM. Addressing the difficulties of students and teachers. Engaging the students

\section{Cost structure}

Cost structure.

1. Most important costs
(a) Marketing is the main cost
(b) Customer relationship management is the next cost
(c) Online platform is the third important cost

160

2. Key resources that are most expensive

(a) Cost of acquiring a student through marketing efforts

3. Key activities that are expensive

(a) Maintaining the customer relationships through CRM

165

(b) Maintaining the online platform

(c) Marketing on Facebook and others 


\section{Revenue streams}

Revenue streams.

1. Value for which customers are paying

170

(a) Students can learn the content in one month, and then they can start teaching and earn for the same

(b) Students and teachers can showcase their work to industry users

2. Revenue

(a) We propose to charge Rs 600 per hour from students

(b) We propose to pay Rs 325 per hour to the teachers

(c) There is additional revenue when students and teachers work for industry users. Students and teachers would share some of the earnings to our platform, if they want guidance and more clients from our platform in future

\section{Business plan}

Introduction. This project is about teaching $\mathrm{R} \& \mathrm{D}$ to school going students. This project prepares a large talent pool which the industry users can use to do their R\&D work.

1. Confidentiality agreement

(a) The author of this document reserves all the copyrights of this document

2. Executive summary

(a) There are three customers in this project (a) Students (b) Teachers (c) Industry users. Students learn about the authenticated websites where original research is published. They further learn to write research material and then publish it on scientific platforms. Students learn to draw mind maps and fishbone diagrams on the relevant research topics. Students would then be connected to industry users where students can sell the research they have done. 
3. Business focus

(a) Mission statement: The goal is to catch them young. We teach young minds to do scientific research. Seeing the science in action student would be further motivated in its studies.

(b) Business details: We are a Pvt Ltd company. Our team consists of highly experienced professionals in Engineering.

(c) Professional support: We are increasing our base of industry clients who can provide suitable research problems to students. We have identified several research problems which a student can work on. Sample work done by our students is attached in the later section of this business plan.

(d) Personal profiles: The promoter of this company, Yoshida Rao, is B.Tech in Mechanical Engineering from IIT Roorkee and M.Tech in Construction Technology and Management from IIT Chennai. He is also GATE Rank 2 holder. He has also experience in working in L\&T and Nuclear power corporation. Apart from this he also has experience in teaching students in various Engineering colleges.

(e) Operations: Our first step is to train the teachers according to our requirements. Also we require to show some relevant research content to students which they can develop further. Our team is already working on these two aspects.

(f) Operations Cycle: Students come to the platform and give its areas of interest. A teacher teaching that area of interest is connected to the student. A typical of 10 one hour classes are required to complete the task. After that the student can prepare work samples and submit to the platform. If work samples are found OK then the student would be given the option of connecting to industry users, or else the student can also teach at our platform and earn money.

(g) Payment: We are proposing a payment of Rs 600 per hour class from a student. We propose to pay Rs 325 per hour to the teacher. These figures are around industry standard these days. Industry 
users would pay some fees to have students and teachers to work for them.

(h) Aims and Objectives

i. Short term: To develop an online platform. To train 100 teachers using the platform

ii. Medium term: To do marketing to bring in more students

iii. Long term: To have tie ups with industry users

4. Market Research

(a) Client Research: There is a huge amount of R\&D work available in the country. There are students who want to learn more. This is the concept of the gig economy that we are seeing today.

(b) Evidence of customer demand: We are in touch with industry users who want people for their R\&D work.

(c) Competitor profiling: There is a lot of online market in education. And more people are feeling comfortable with it.

(d) SWOT analysis:

i. Strengths: We have people working with us who have 20 plus years of experience in $\mathrm{R} \& \mathrm{D}$ and teaching.

ii. Weaknesses: We need investments for developing our online platform.

iii. Opportunities: R\&D field is booming in the country. iv. Threats:

5. Marketing plan

(a) Services we offer:

i. Students learn to do R\&D

ii. Teachers get to earn money

iii. Both these users get to showcase their work to industry users

(b) Unique selling point: We have a team which is already having an head start in industry research

(c) Pricing policy: We are charging Rs 600 per hour from students, and paying Rs 325 per hour to teachers. This is industry standard. 
(d) Sales and Marketing: Our sales and marketing strategy is under development

6. Financial plan

\section{Work done by our Students and Teachers}

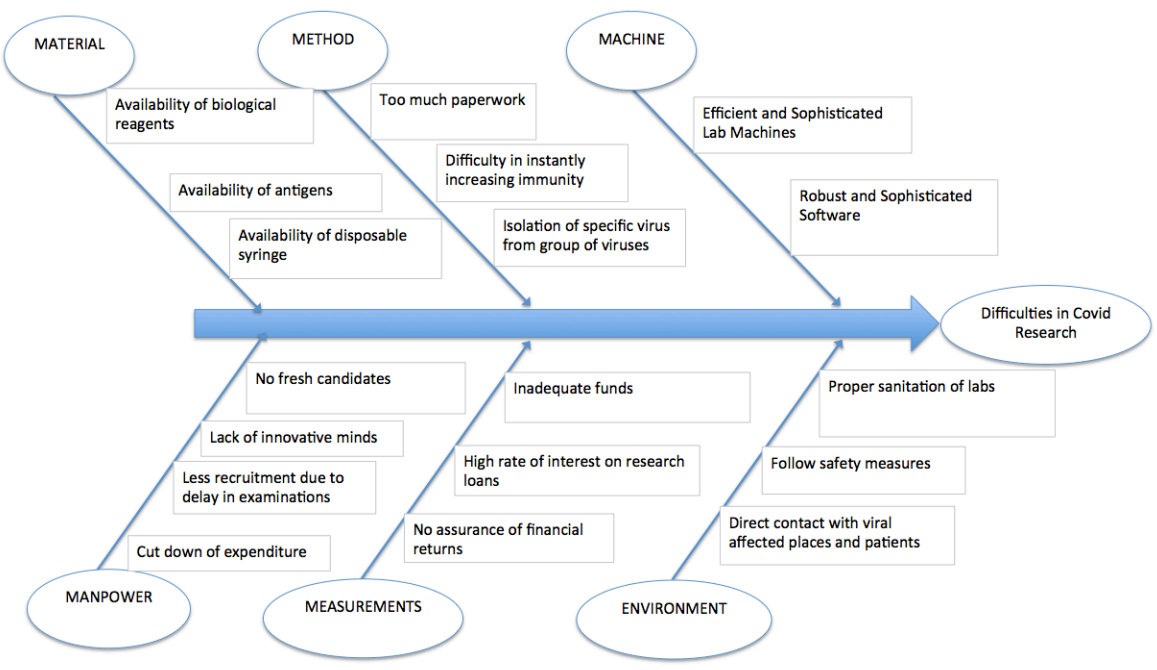

Figure 1: This fishbone diagram discusses the challenges in Covid research. 


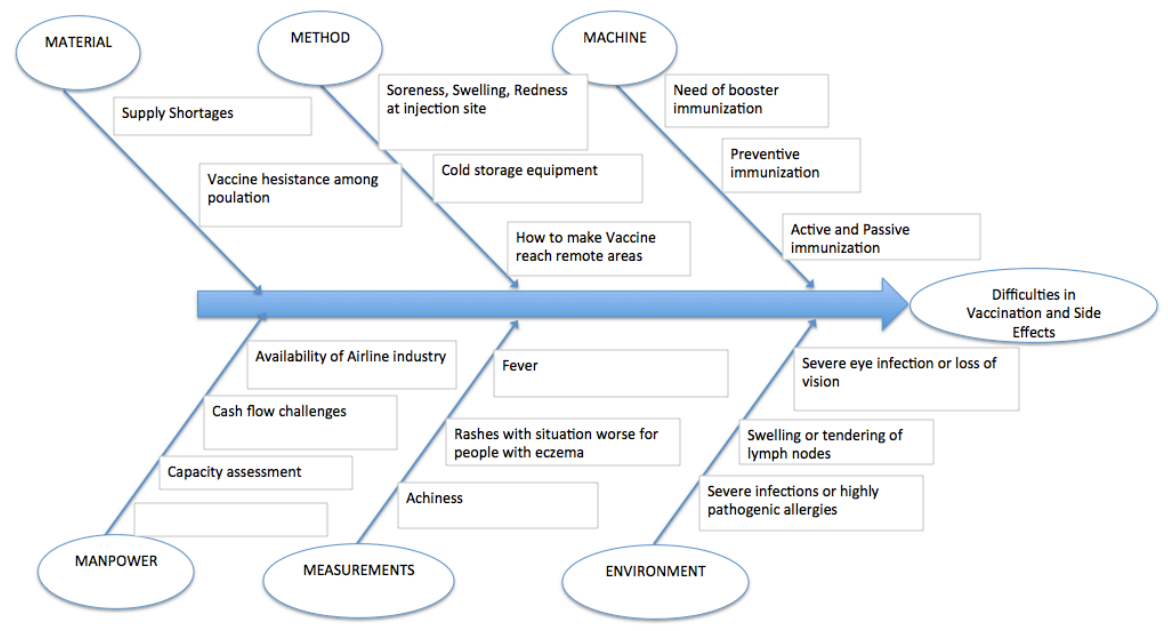

Figure 2: This fishbone diagram discusses difficulties in Covid Vaccination.

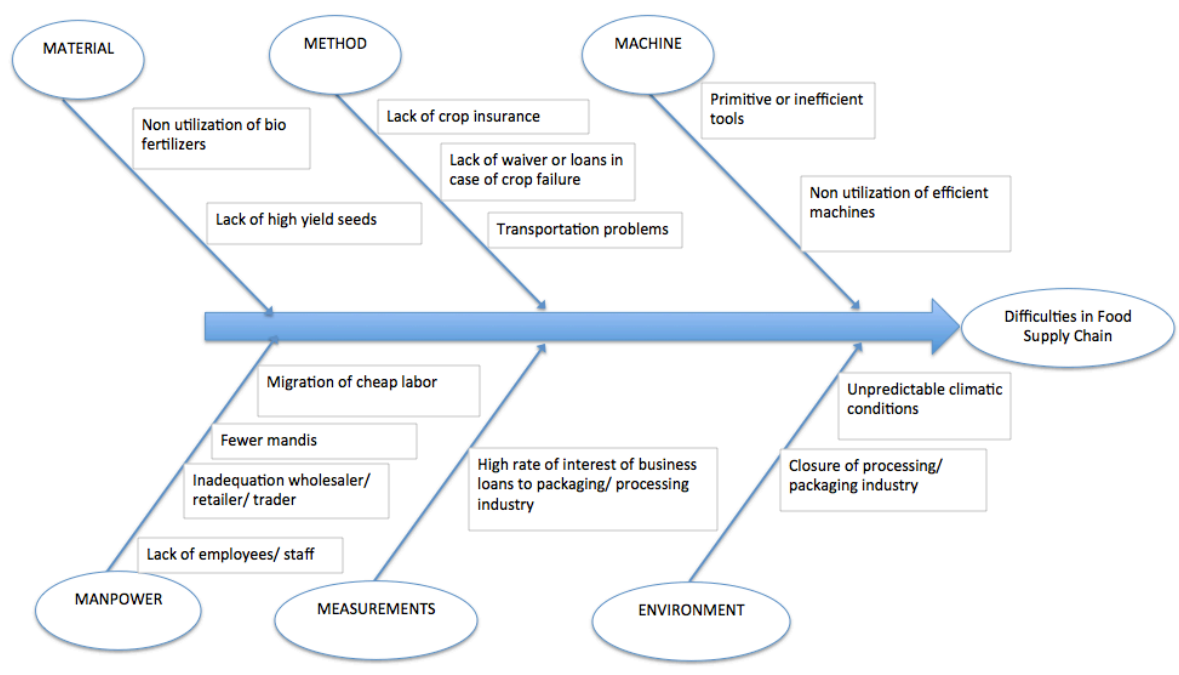

Figure 3: This fishbone diagram discusses difficulties in Food Supply Chain. 


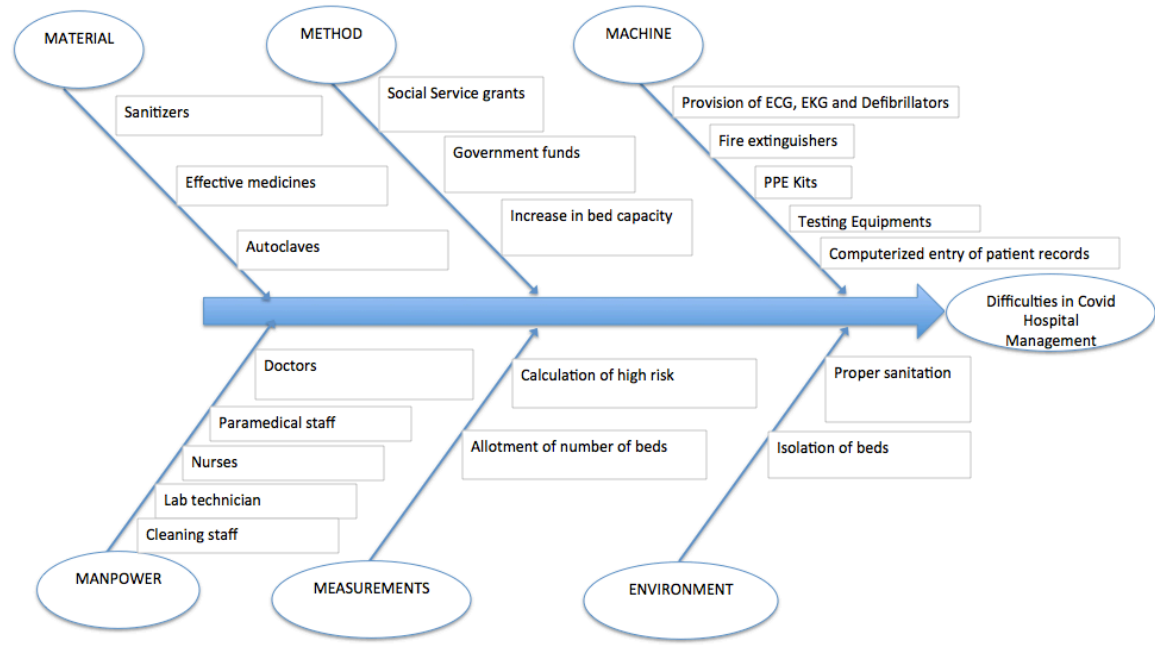

Figure 4: This fishbone diagram discusses difficulties in Covid Hospital Management.

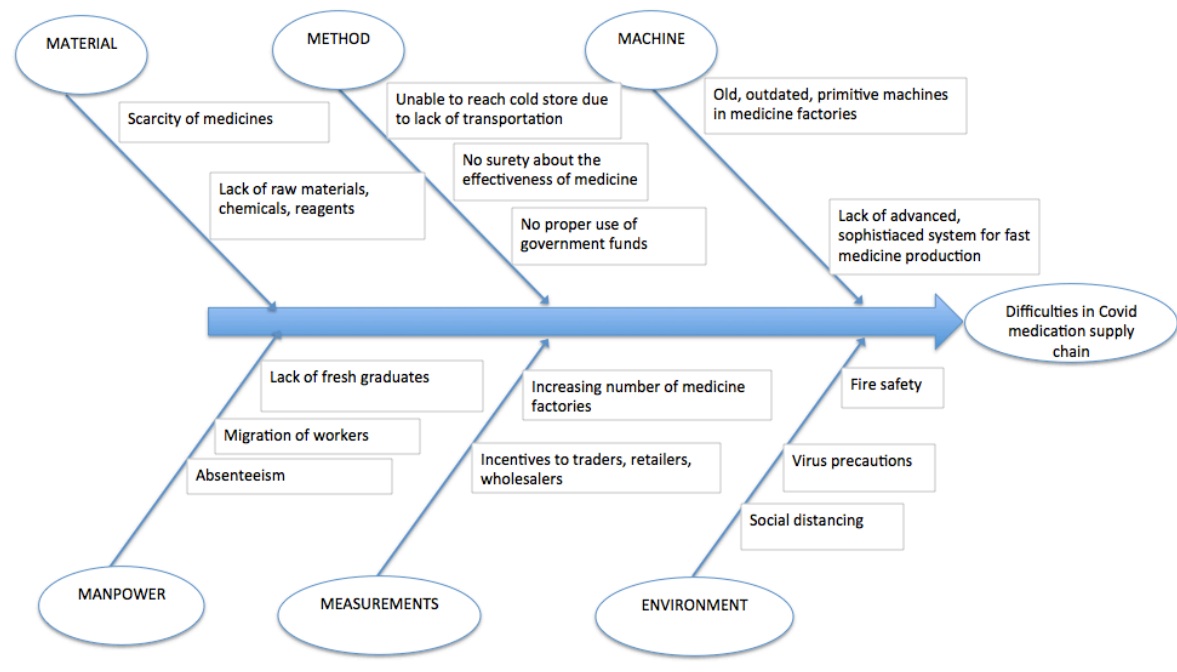

Figure 5: This fishbone diagram discusses difficulties in Covid Medication Supply Chain. 


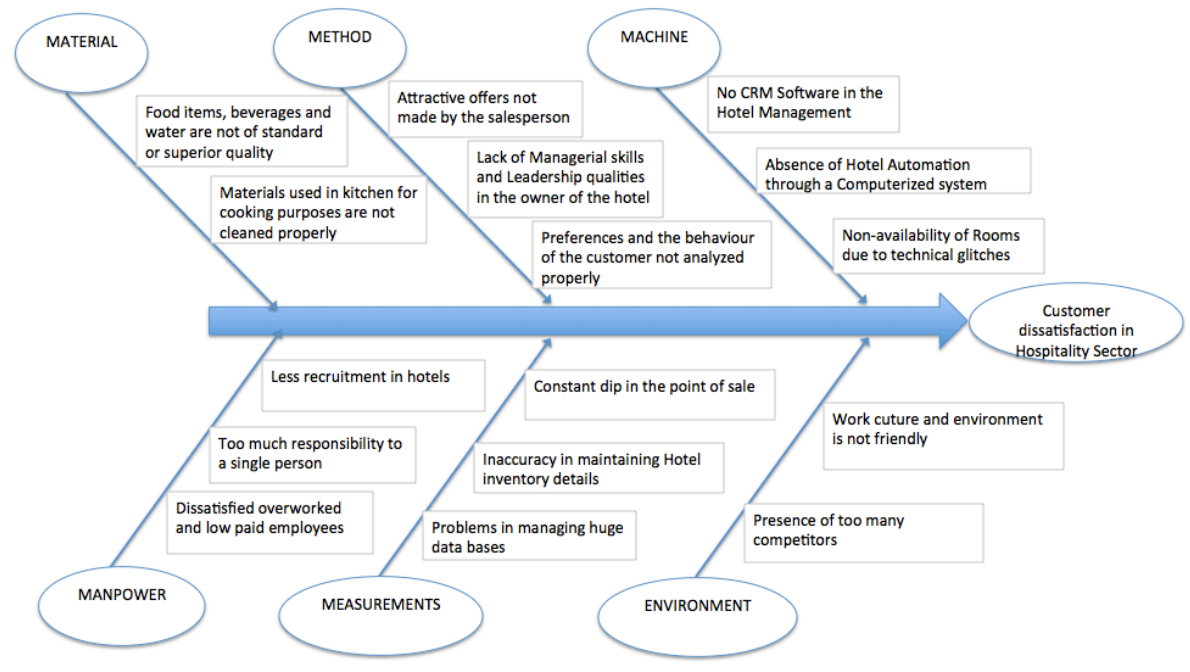

Figure 6: This fishbone diagram discusses functioning of Hospitality sector.

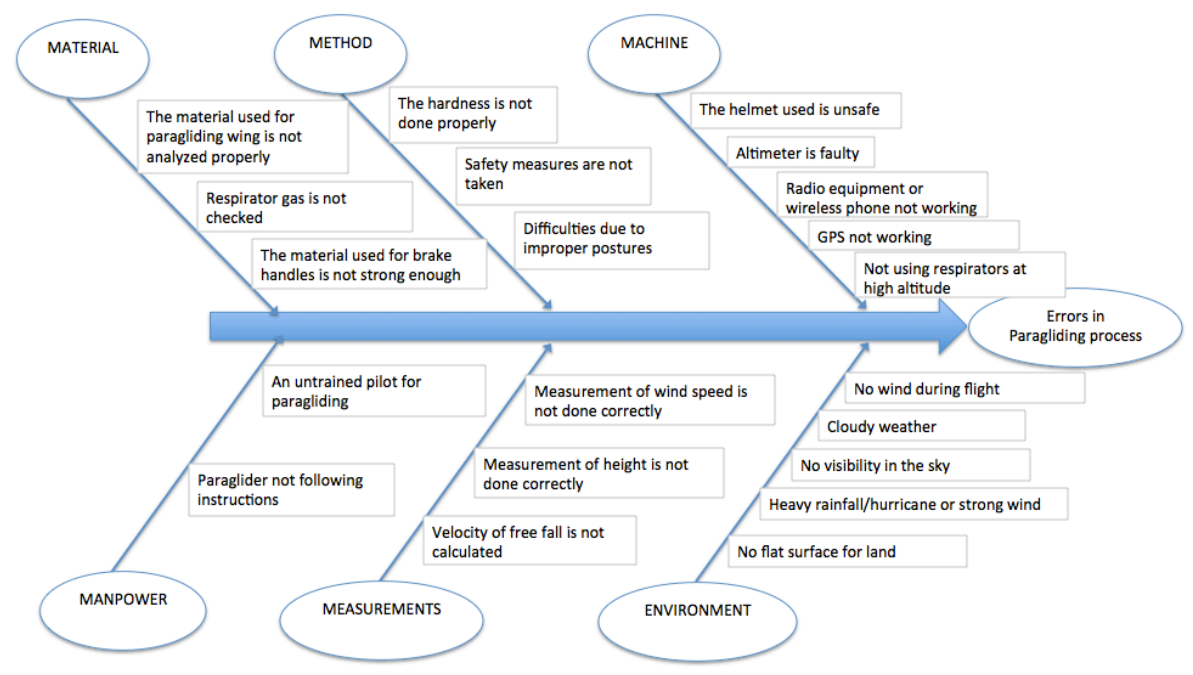

Figure 7: This fishbone diagram discusses functioning of Paragliding. 


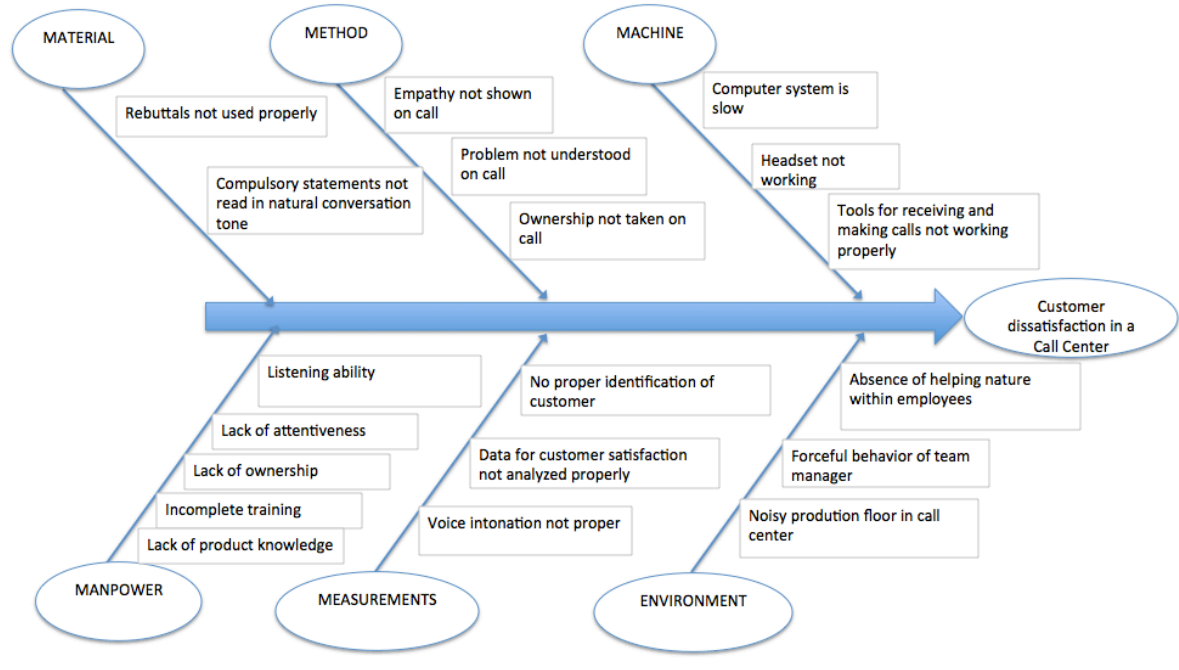

Figure 8: This fishbone diagram discusses functioning of a Call Centre and BPO. 


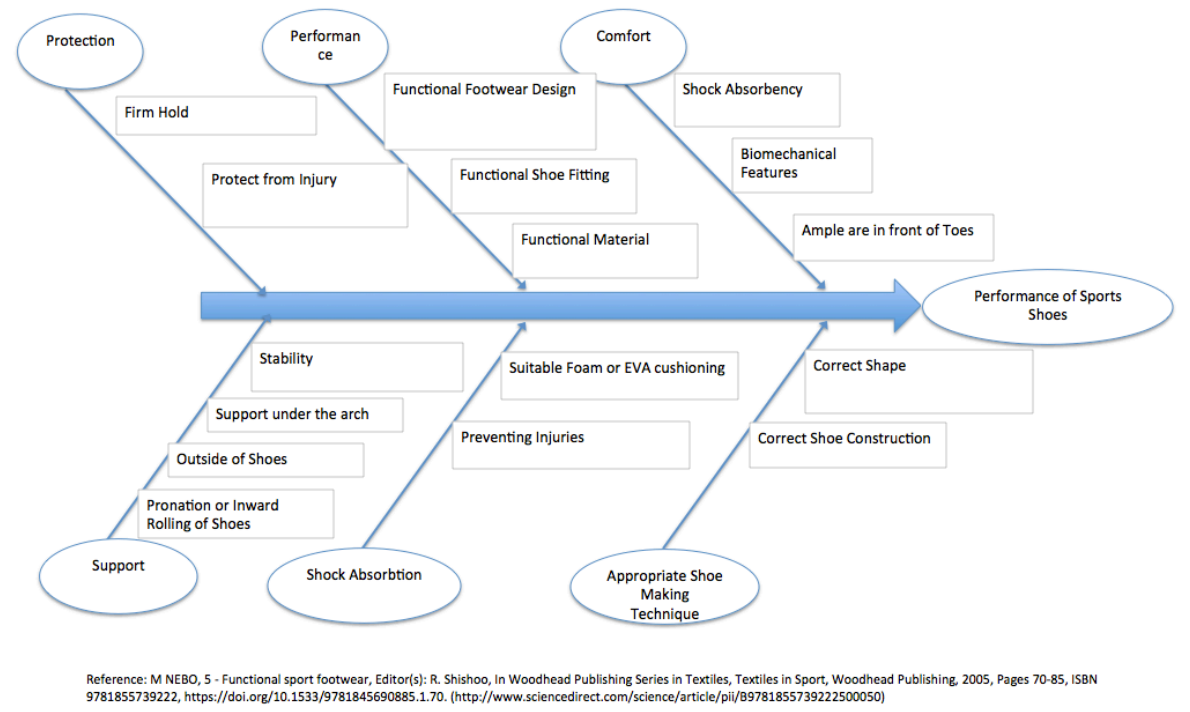

Figure 9: This fishbone diagram discusses factors affecting performance of sports shoes. Rerence: M NEBO, 5 - Functional sport footwear, Editor(s): R. Shishoo, In Woodhead Publishing Series in Textiles, Textiles in Sport, Woodhead Publishing, 2005, Pages 70-85, ISBN 9781855739222 NEBB( (2015) 


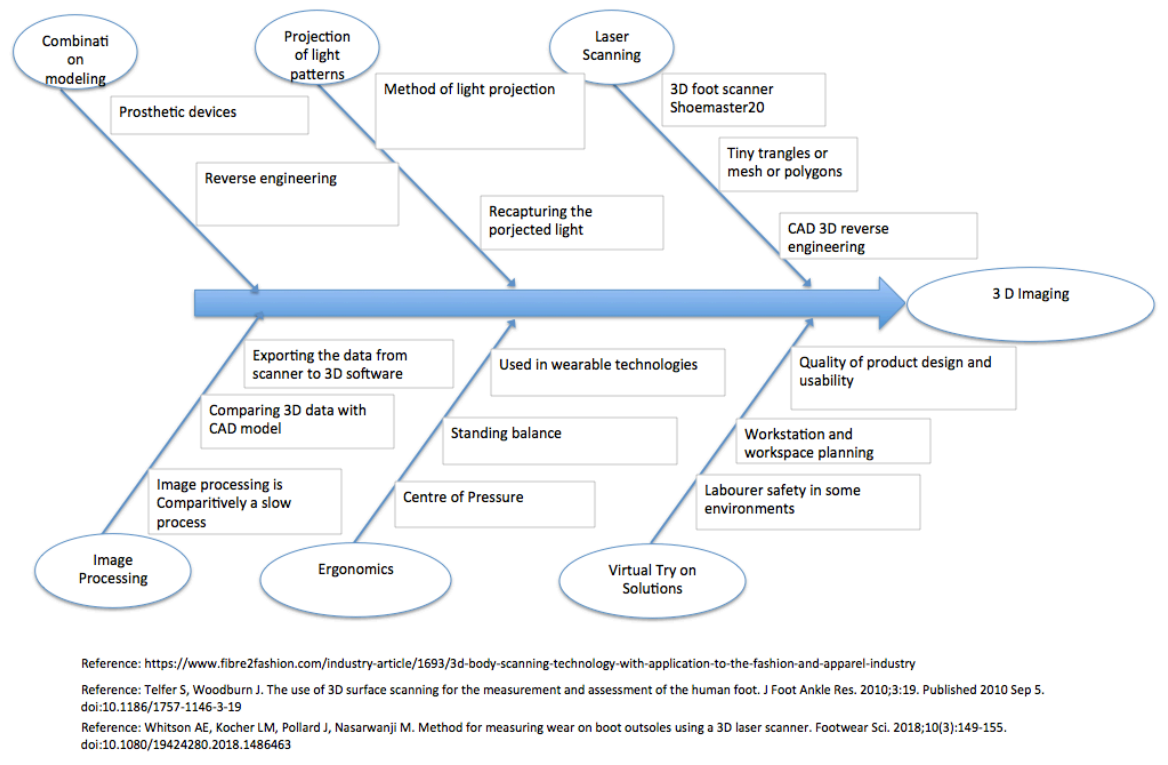

Figure 10: This fishbone diagram discusses factors affecting 3D imaging in textile and shoes indusry.https://www.fibre2fashion.com/industry-article/1693/3d-bodyscanning-technology-with-application-to-the-tashion-and-apparel-industry, Telter and woodburn (2010), Whitson et all (2018) 


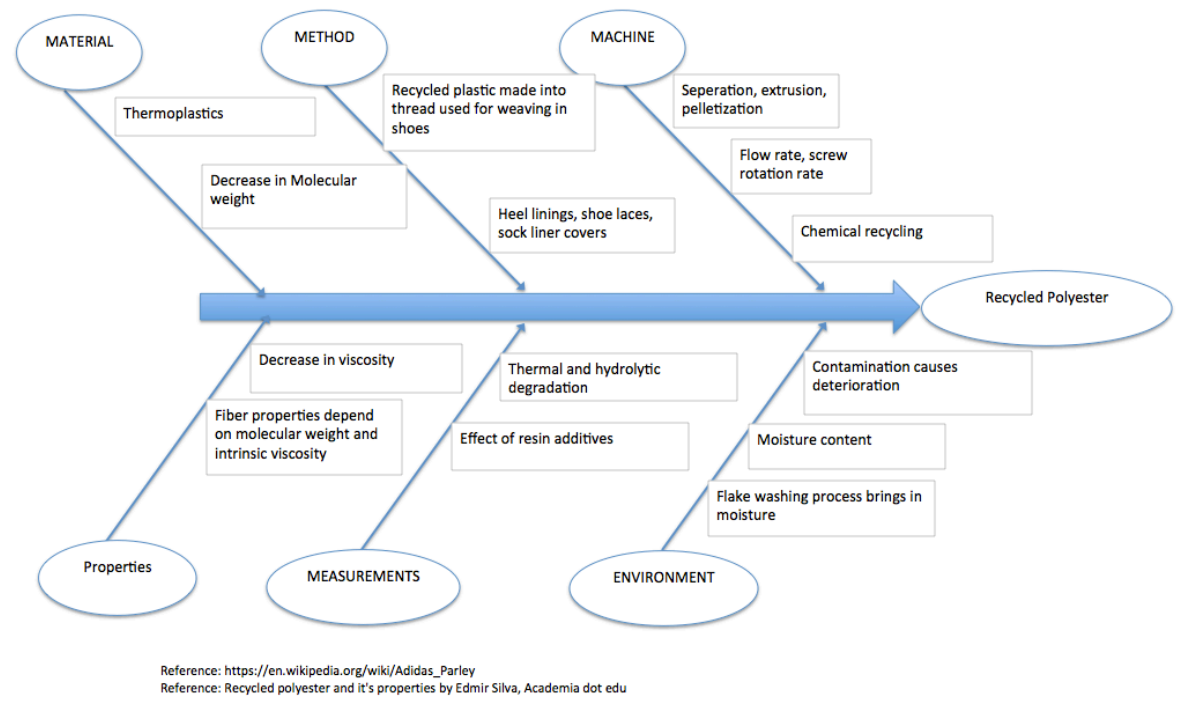

Figure 11: This fishbone diagram discusses factors affecting use of Recycled Polyester in Textile and Shoes industries. Recycled polyester and it's properties by Edmir Silva, Academia dot edu 


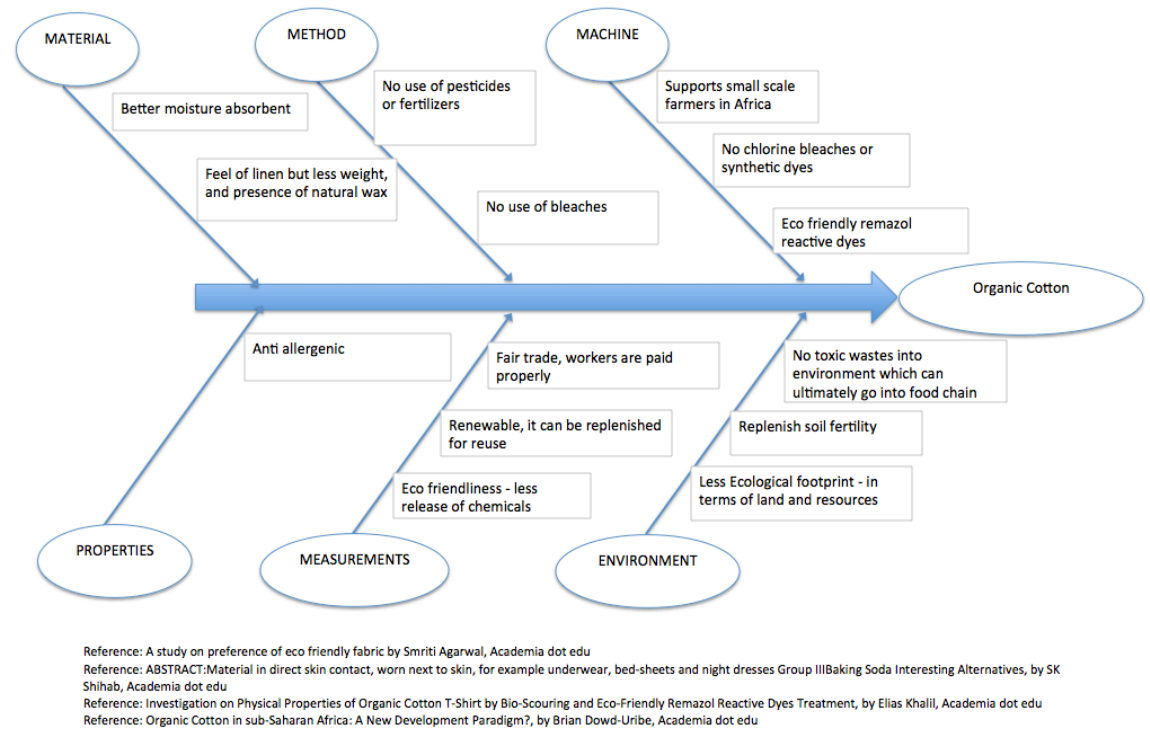

Figure 12: This fishbone diagram discsusses factors affecting use of Organic Cotton in textile and shoes industries.

1. A study on Preference of the Eco-triendly Fabric-Organic Cotton and Bamboo by Smriti Agarwal at Academia dot edu,

2. ABSTRAC'I:Material in direct skin contact, worn next to skin, for example underwear, bed-sheets and night dresses Group IIIBaking Soda Interesting Alternatives by S K Shihab at Academia dot edu,

3. Investigation on Physical Properties of Organic Cotton 'T-Shirt by BioScouring and Eco-Friendly Remazol Reactive Dyes 'Treatment by Elias Khalil at Academia dot edu,

4. Organic Cotton in sub-Saharan Atrica: A New Development Paradigm? by Brian Dowd-Uribe at Academia dot edu 


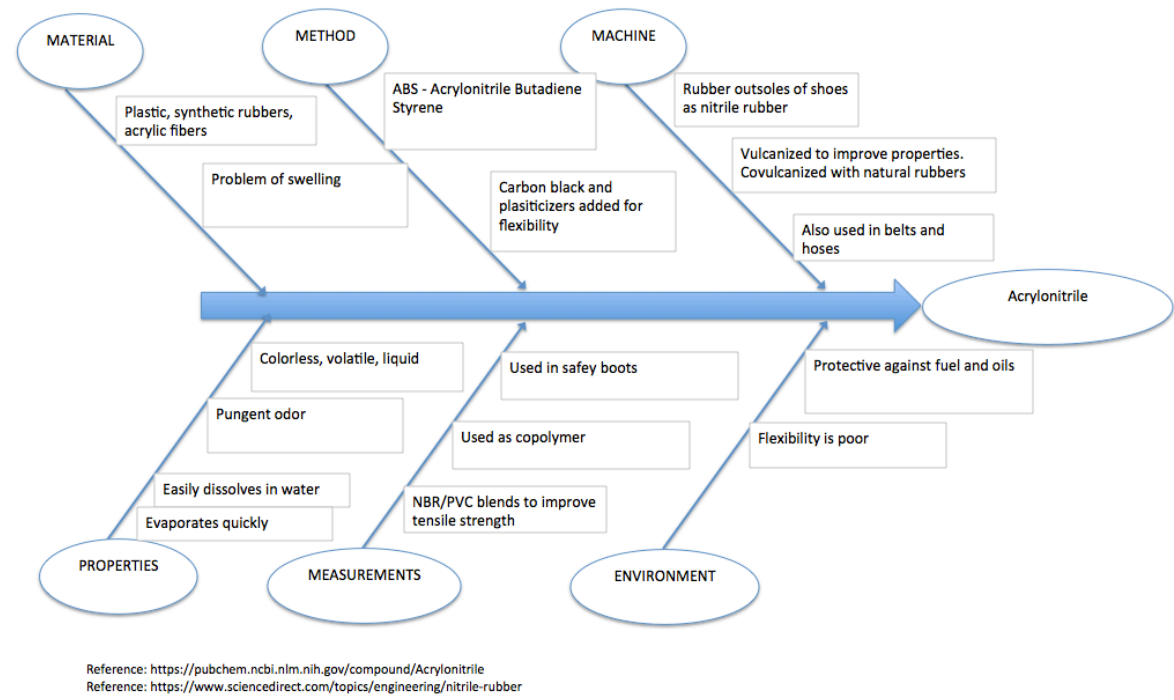

Figure 13: This fishbone diagram discusses factors affecting use of Acrylonitrile in shoes industry and it's impact on environment. https://pubchem.ncbi.nlm.nih.gov/compound/ Acrylonitrile, https://www.sciencedirect.com/topics/engineering/nitrile-rubber 


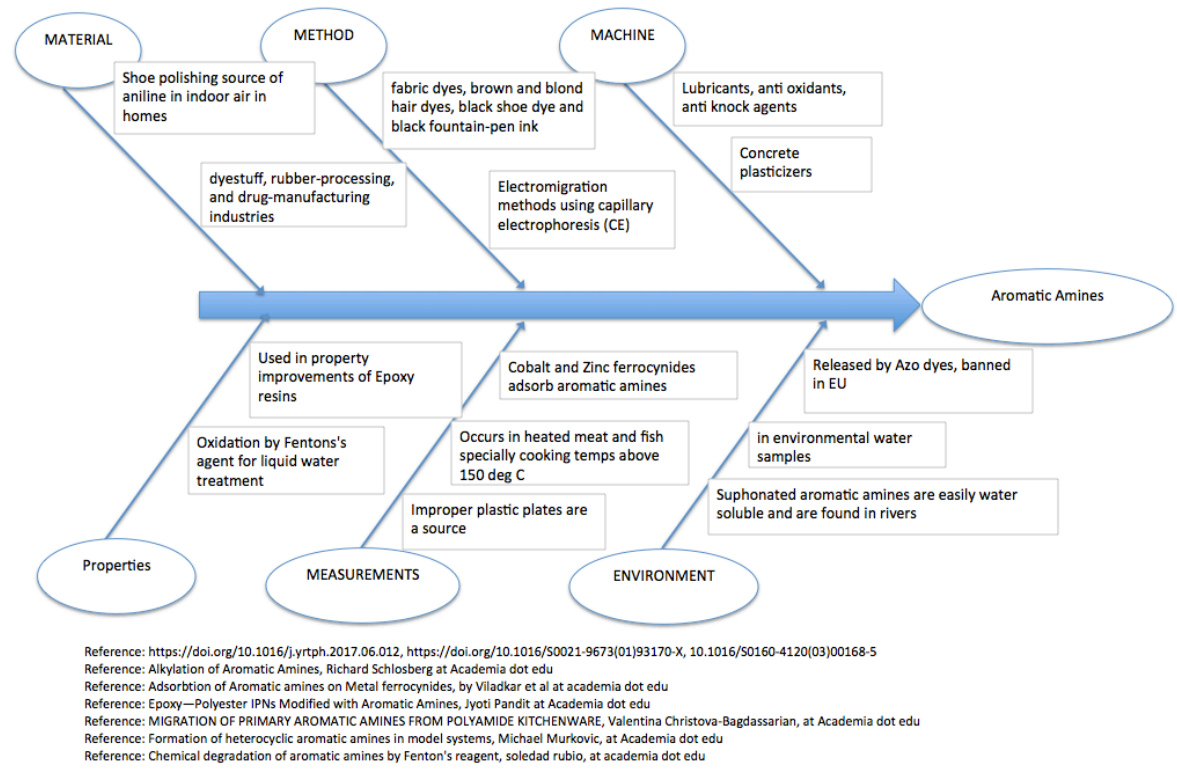

Figure 14: This fishbone diagram discusses factors affecting use of Aromatic Amines in shoes industry and it's impact on environment.

1. Brschweiler and Merlot (2017) Gennaro et all (15990) Zhu and Aikawa $(20104)$

2. EpoxyPolyester IPNs Modified with Aromatic Amines by Jyoti Pandit at Academia dot edu

3. MIGRATION OF PRIMARY AROMATTC: AMINES FROM POLYAMIDE KITCHENWARE by Valentina Christova-Bagdassarian at Academic dot edu

4. Casero et al. (1997) 


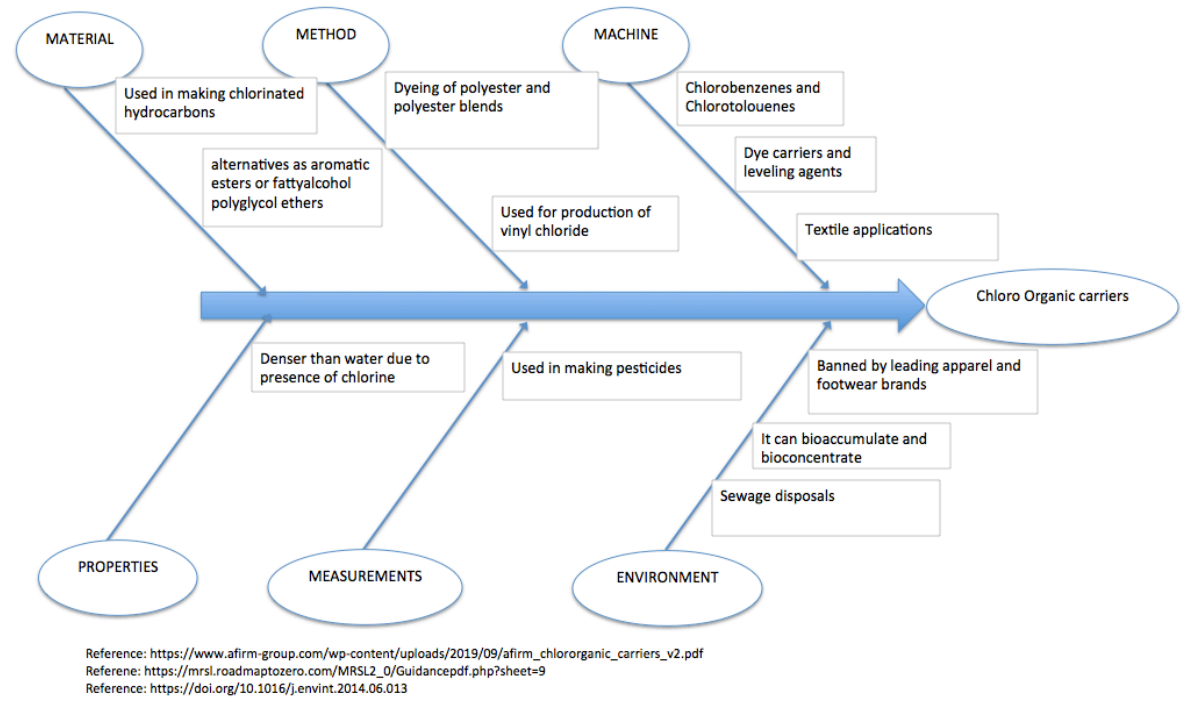

Figure 15: This fishbone diagram discusses factors affecting use of Chloro Organic Carriers in shoes industry and it's impact on environment.

1. https://www.afirm-group.com/wp-content/uploads/2019/09/ afirm_chlororganic_carriers_v2.pdf

2. https://mrsl.roadmaptozero.com/MRSL2_0/Guidancepdf .php? sheet $=9$

3. Huang et al. (2014) 


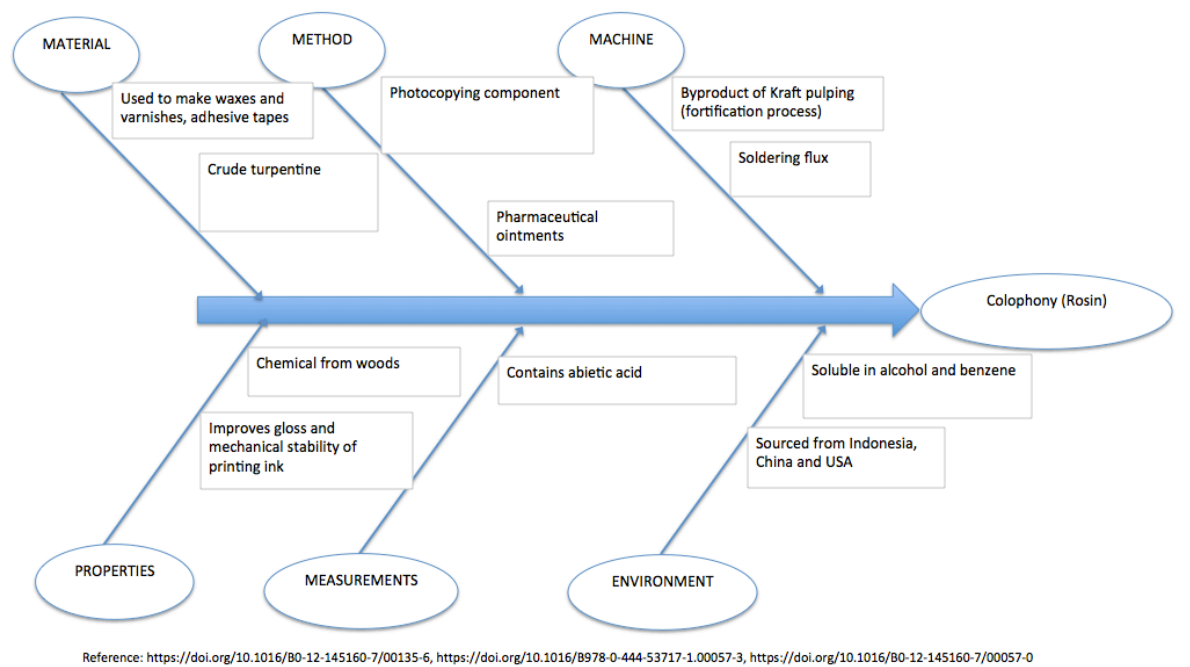

Figure 16: This fishbone diagram discusses factors affecting use of Colophony in shoes industry and it's impact on environment. Hubbe (2004) 2001 (2016) Elder (2004) 


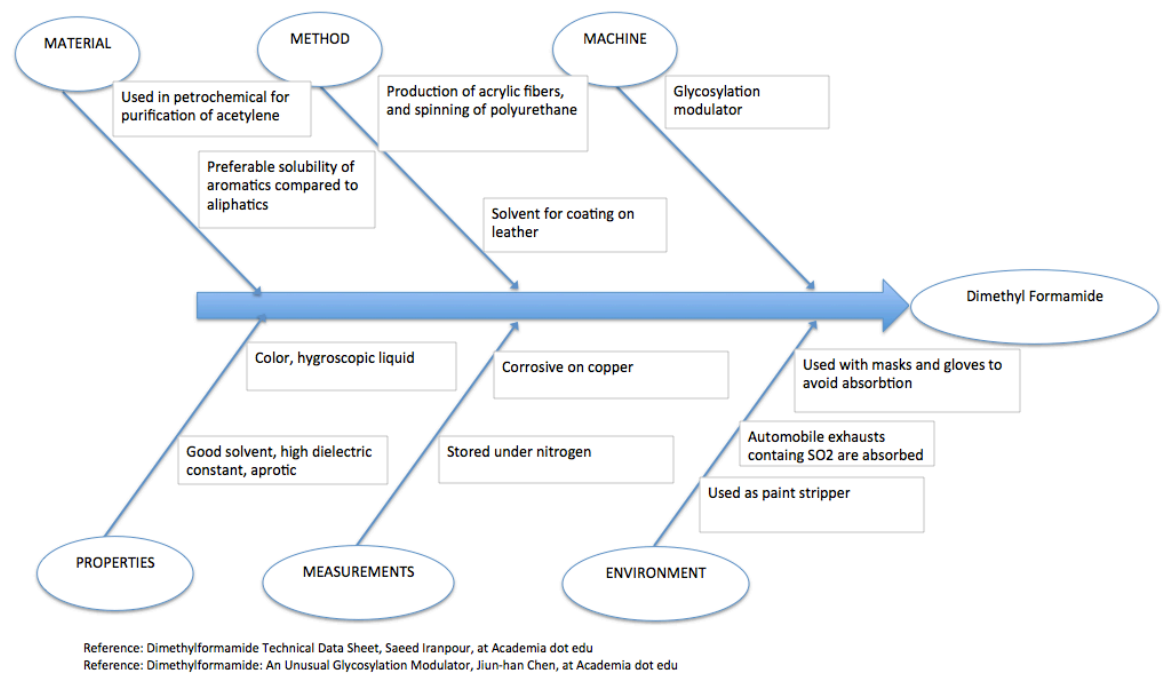

Figure 17: This fishbone diagram discusses factors affecting use of Dimethylformamide in shoes industry and it's impact on environment. Dimethylformamide Technical Data Sheet by Saeed Iranpour at Academia dot edu Dimethylformamide: An Unusual Glycosylation Modulator by Jiun-han Chen at Academia dot edu 


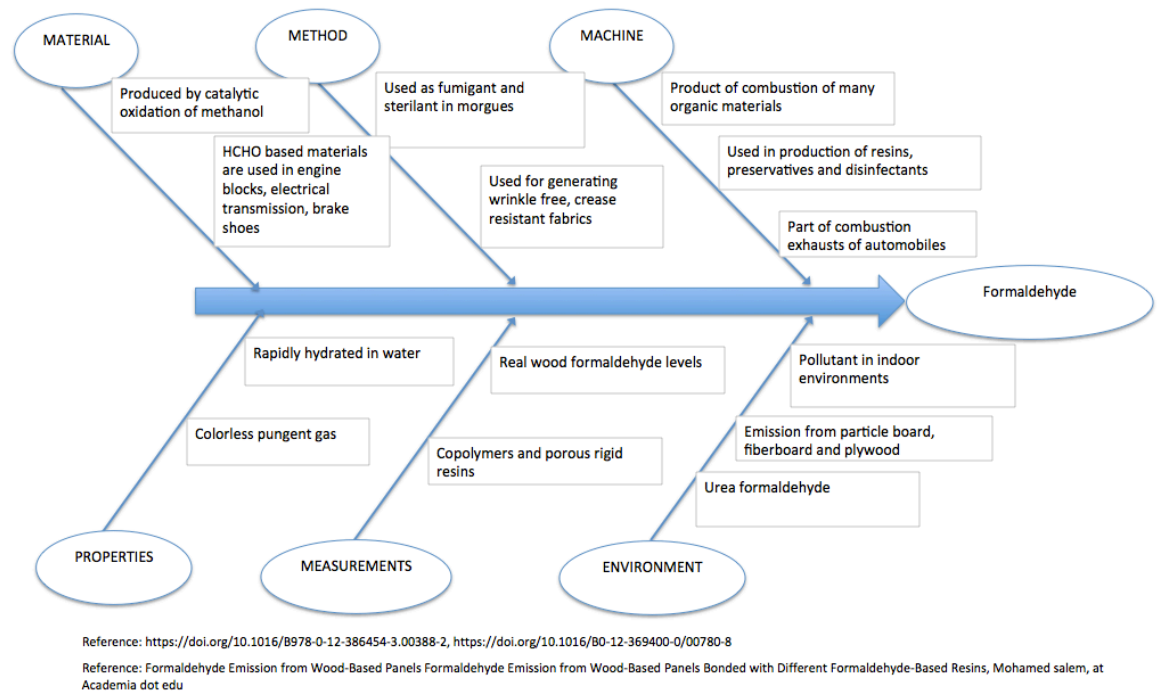

Figure 18: This fishbone diagram discusses factors affecting use of Formaldehyde in shoes industry and it's impact on environment. Abdollahi and Hosseini (2014) Schwela and Kotzias (सUण5) Formaldehyde Emission from Wood-Based Panels Formaldehyde Émission from WoodBased Panels Bonded with Different Formaldehyde-Based Resins by Mohamed salem at Academia dot edu

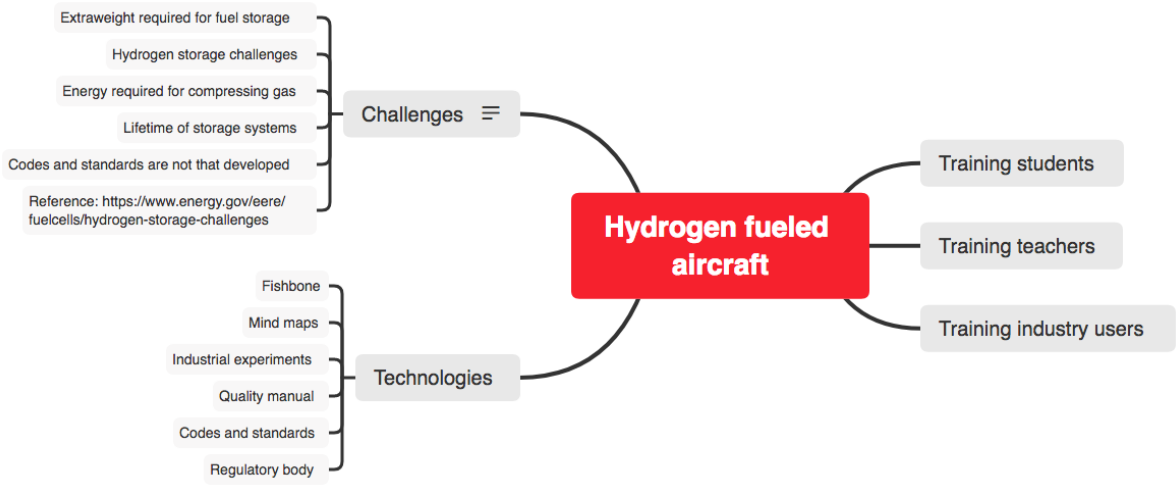

Figure 19: This mindmap discusses factors affecting the usage of Hydrogen Fuel Aircraft. https://www.energy.gov/eere/fuelcells/hydrogen-storage-challenges 


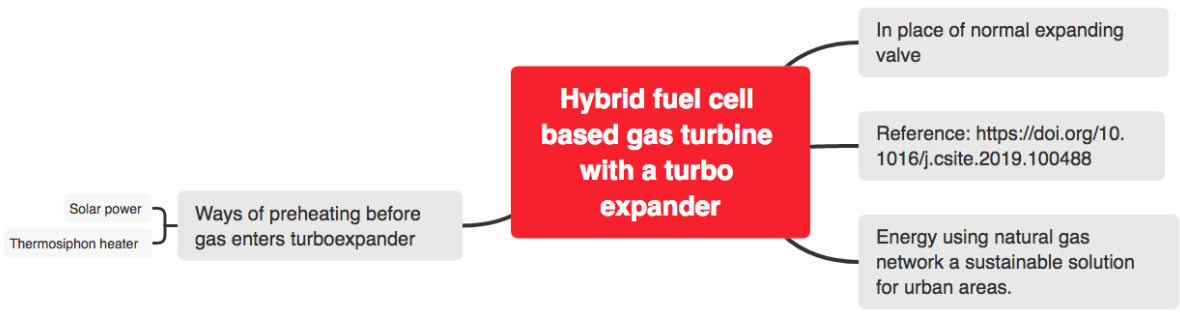

Figure 20: This mindmap discusses factors affecting the usage of Hybrid fuel gas turbine with turboexpander. Golchonbian et al (खणIप)

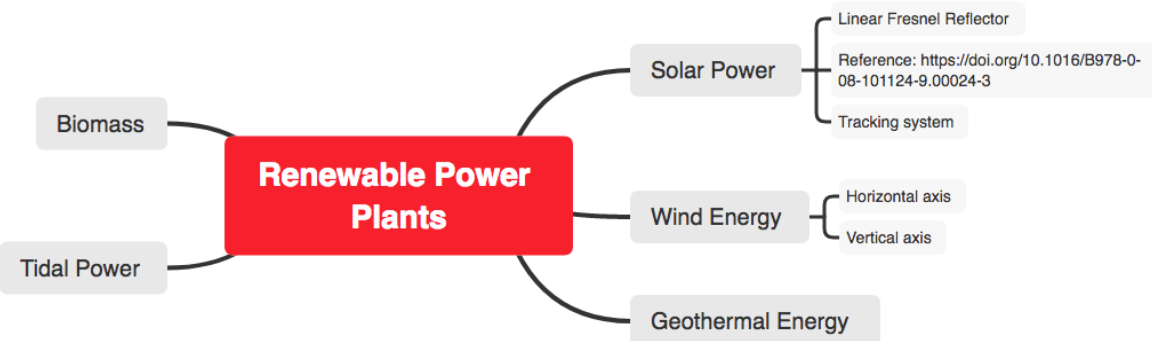

Figure 21: This mindmap discusses factors affecting the usage of Renewable Power Plants. Murty (2017) Ghiani and Pisand (2018) Nitsch et al. (20104) 


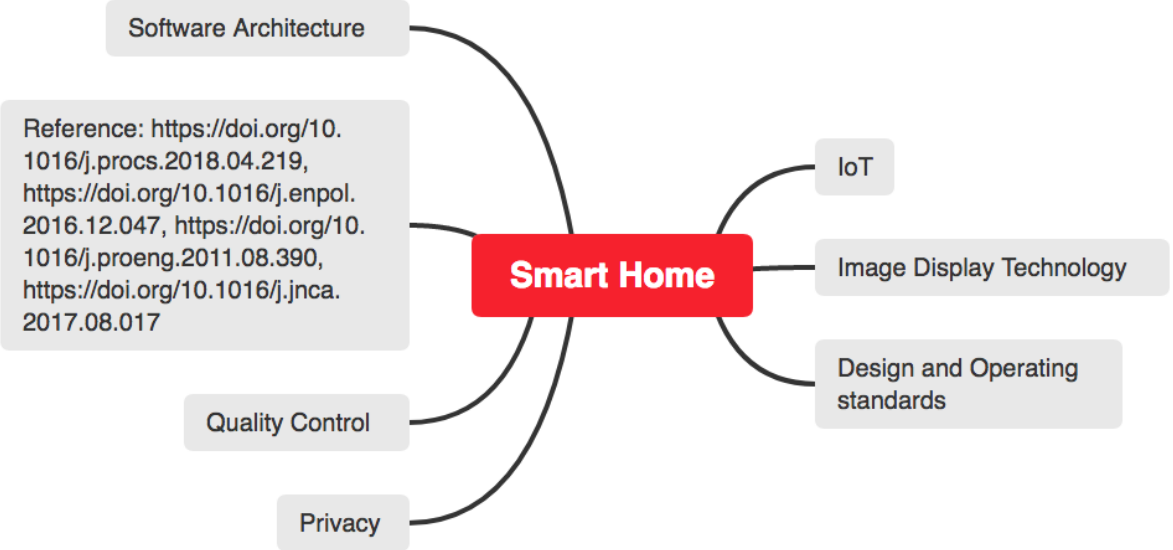

Figure 22: This mindmap discusses factors affecting the functionality of Smart Homes. L1 et all (2018) Wilson et all (2017) Alaa et all (2017) Li and Yul (201])

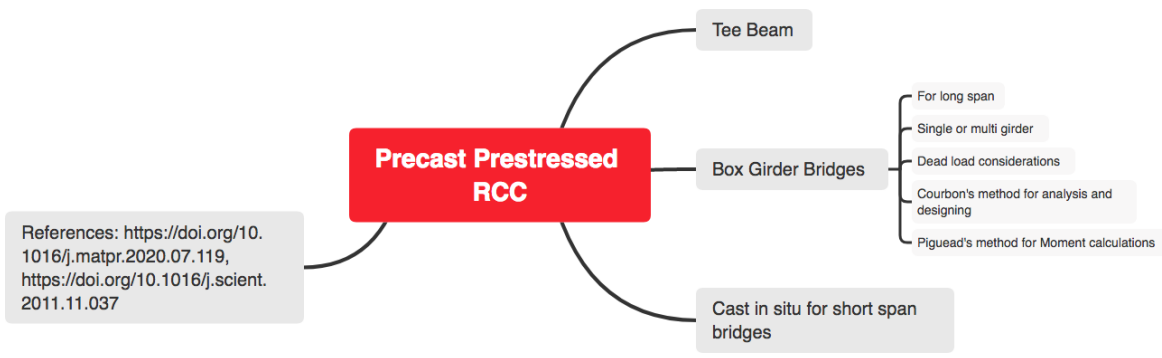

Figure 23: This mindmap discusses factors affecting the Precast and Prestressed RCC.

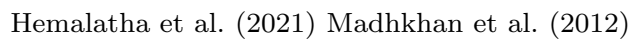




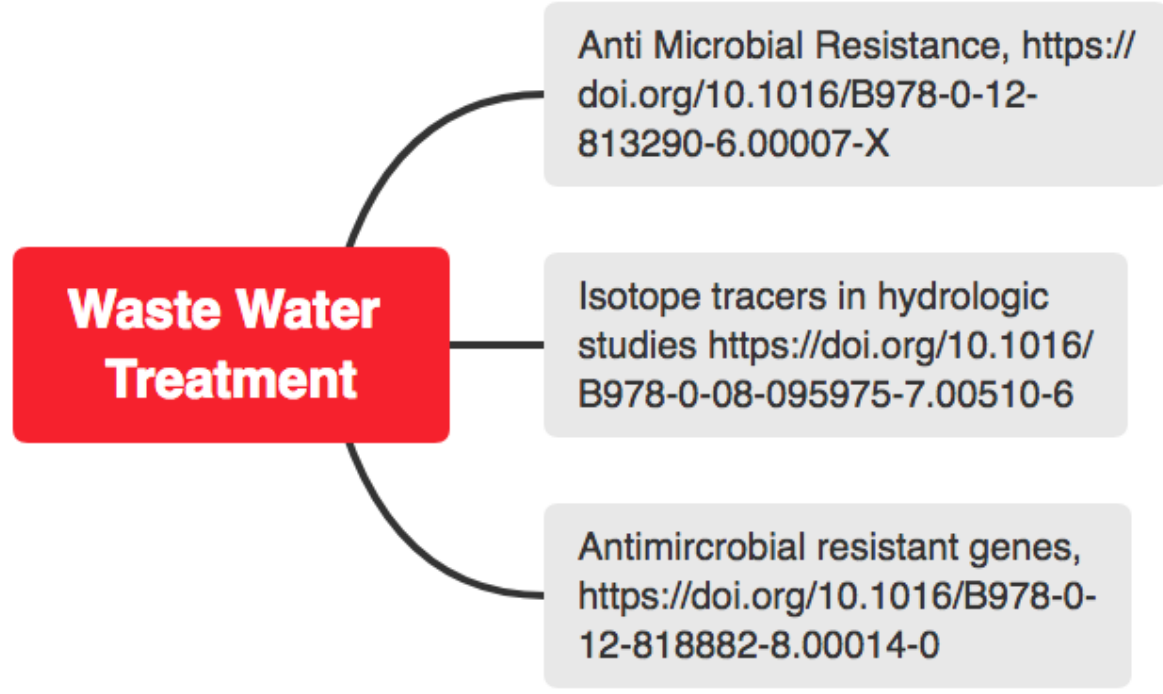

Figure 24: This mindmap discusses factors affecting the Waste Water Treatment. Sanderson

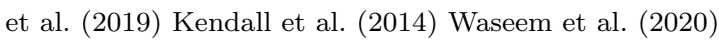

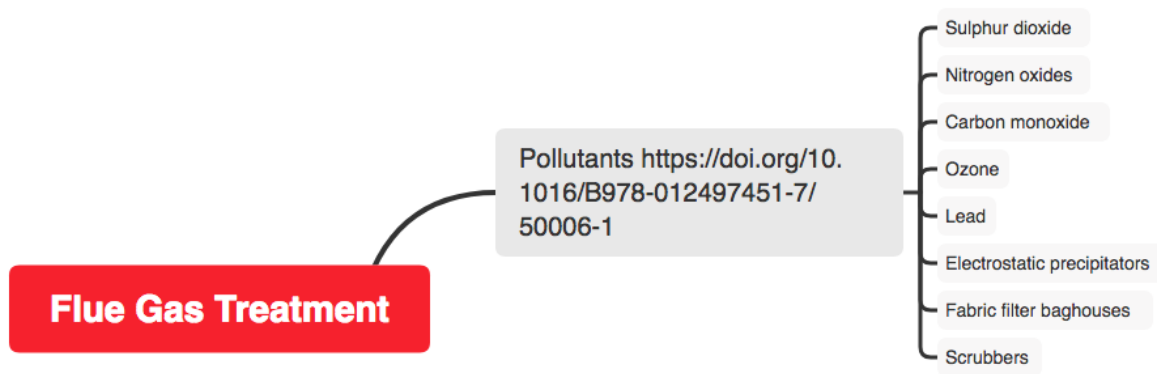

Figure 25: This mindmap discusses factors affecting the Flue Gas Treatment. Miller (2005) Audibert (2006) Miller (सणII) 


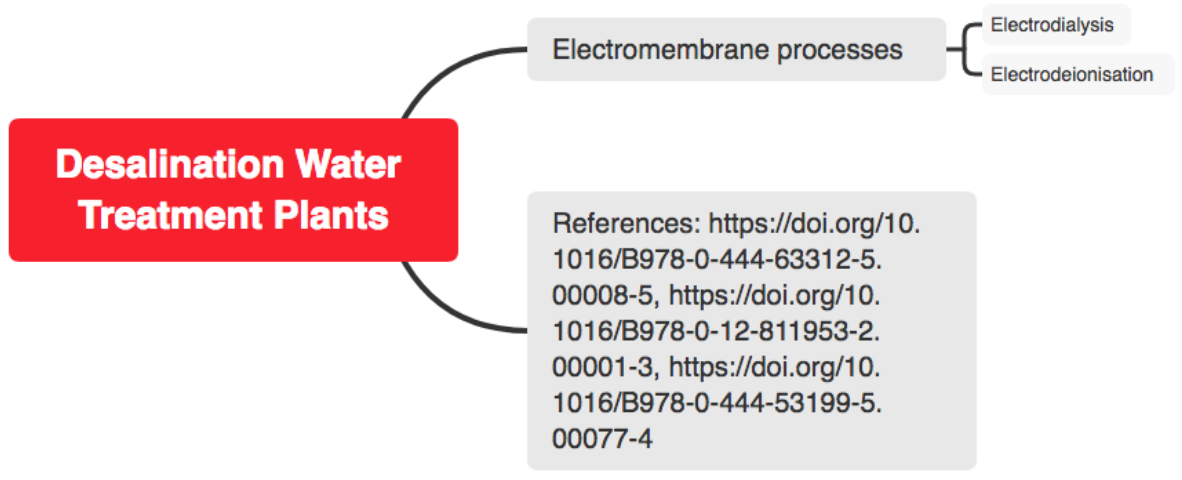

Figure 26: This mindmap discusses factors affecting the Desalination Water Treatment Plants. Kabay et al. (सणाG) Kress (खणाप) Gray et al. (खणा)

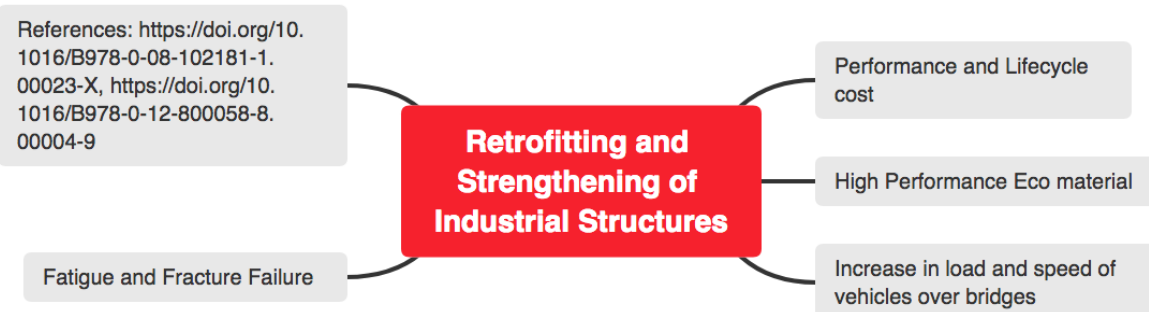

Figure 27: This mindmap discusses factors affecting the Retrofitting and Strengthening of

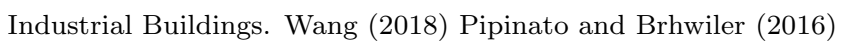




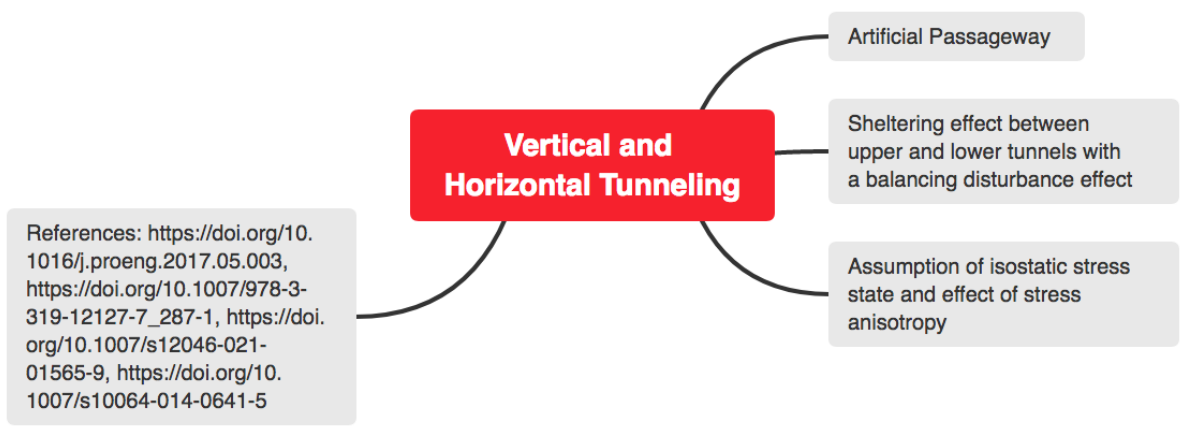

Figure 28: This mindmap discusses factors affecting the Vertical and Horizontal Tunneling.

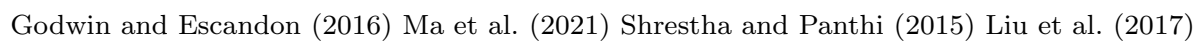

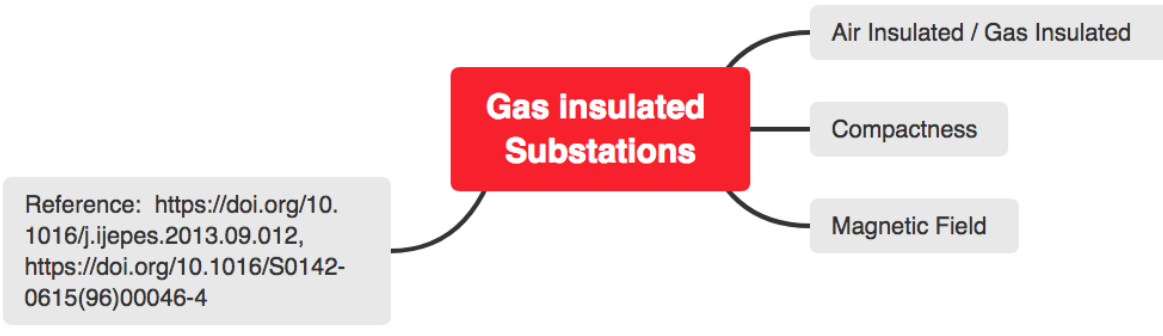

Figure 29: This mindmap discusses factors affecting the Gas Insulated Substations. Nagarsheth and Singh (2014) Farag et al. (11997) 


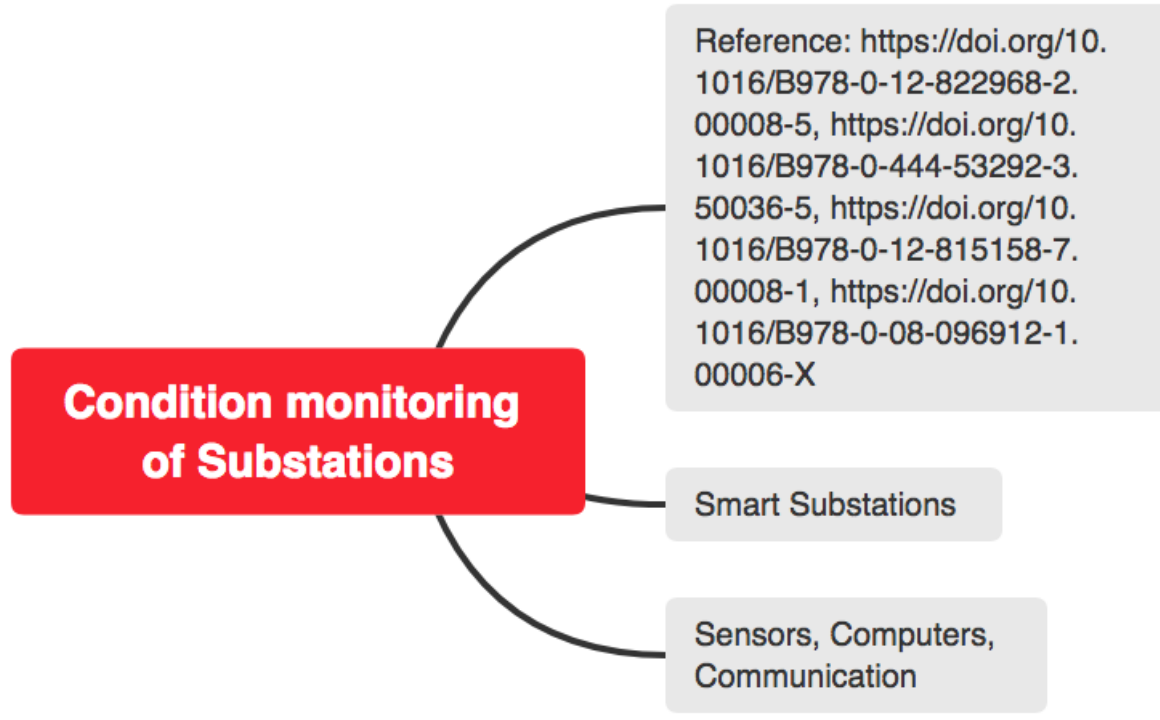

Figure 30: This mindmap discusses factors affecting the Condition Monitoring of Substations. Livl (2020) Attou and Ahmed (2009) Li et al. (2019) Bayliss and Hardy (2012)

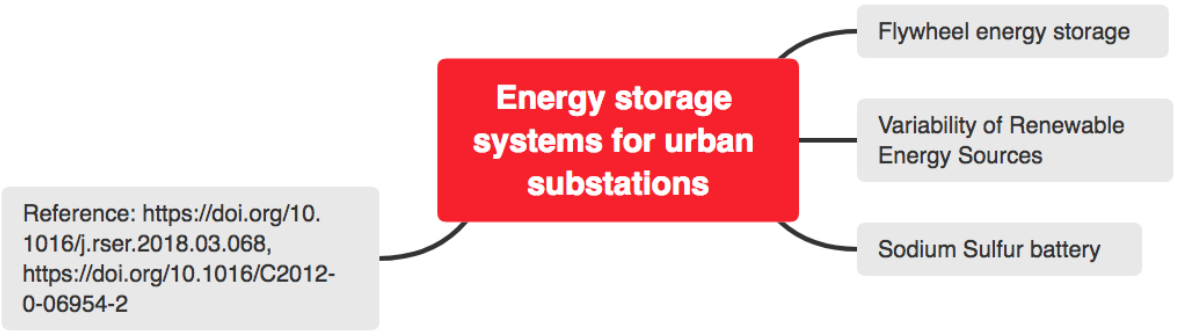

Figure 31: This mindmap discusses factors affecting the Energy Storage Systems. Das et al.

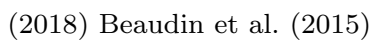




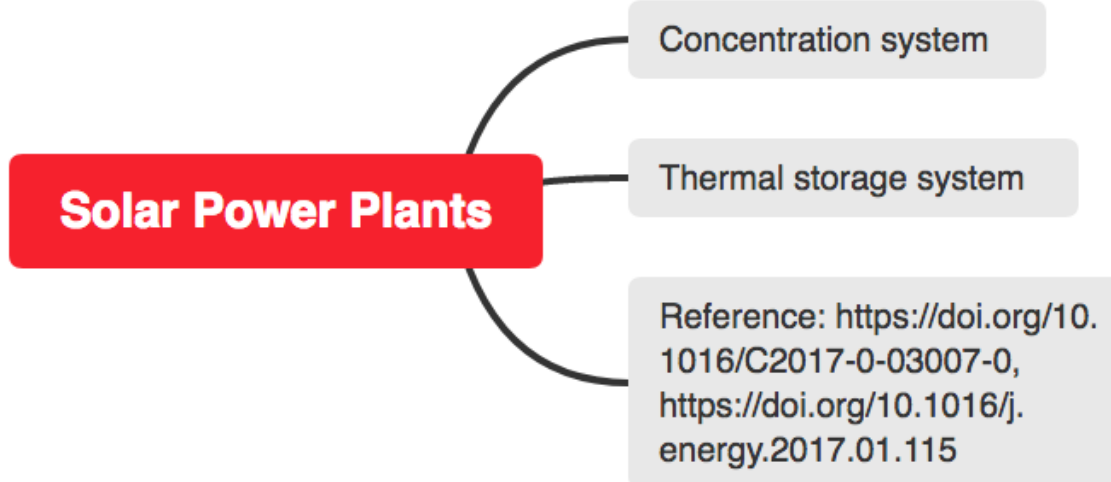

Figure 32: This mindmap discusses factors affecting the Solar Power Plants. Wang (सणप्) Gils et all. (2017)

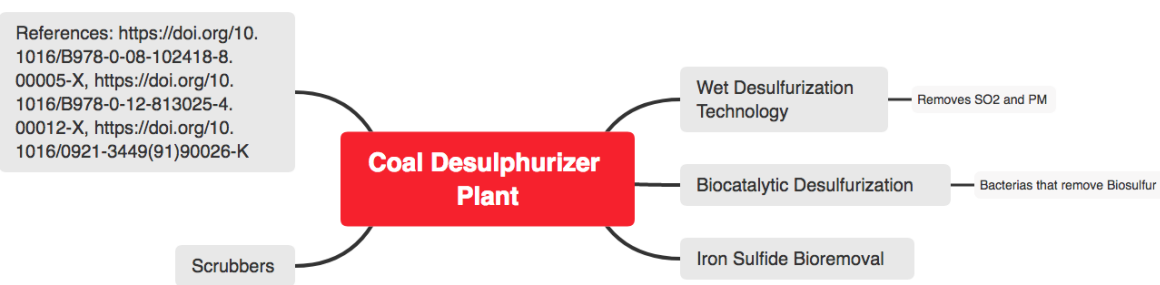

Figure 33: This mindmap discusses factors affecting the Coal Desulphurizer Systems. Zhang (201.9) Speight (2019) Ors et al. (11991) 


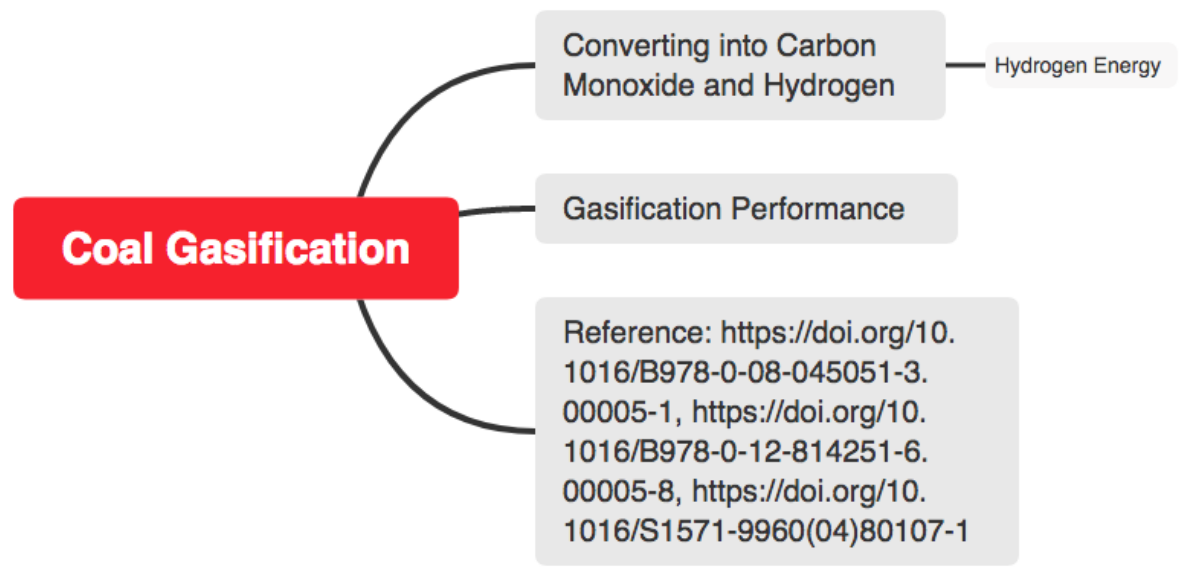

Figure 34: This mindmap discusses factors affecting the Coal Gasification Systems. Wagner

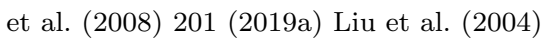

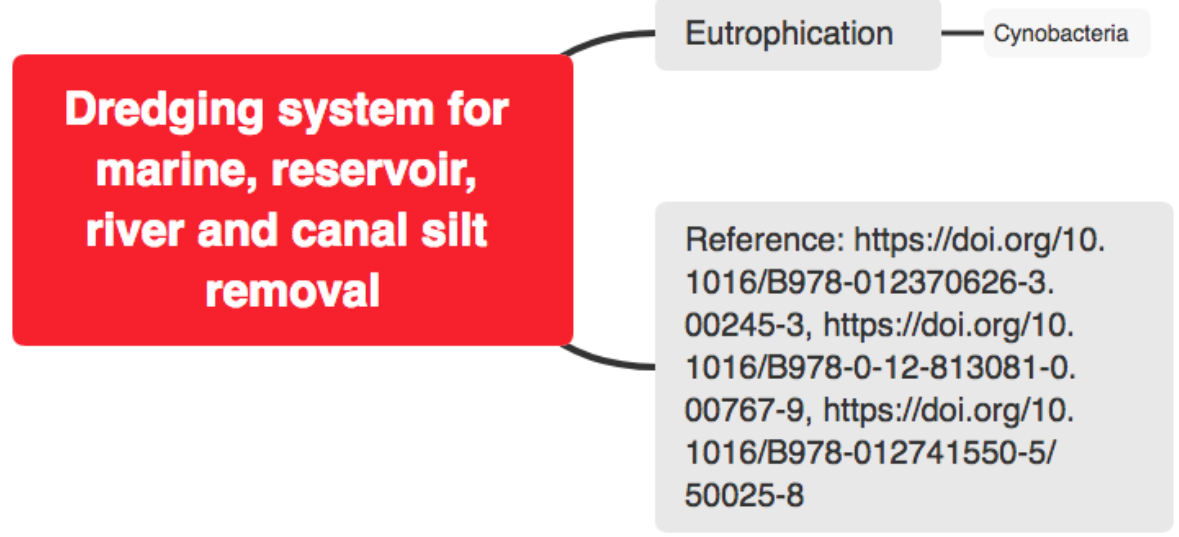

Figure 35: This mindmap discusses factors affecting the Dredging Systems for marine, reservoir, river and canal silt removal. Jeppesen et al. (200.9) Vivian and Murray (200.9) Lembi (20103) 


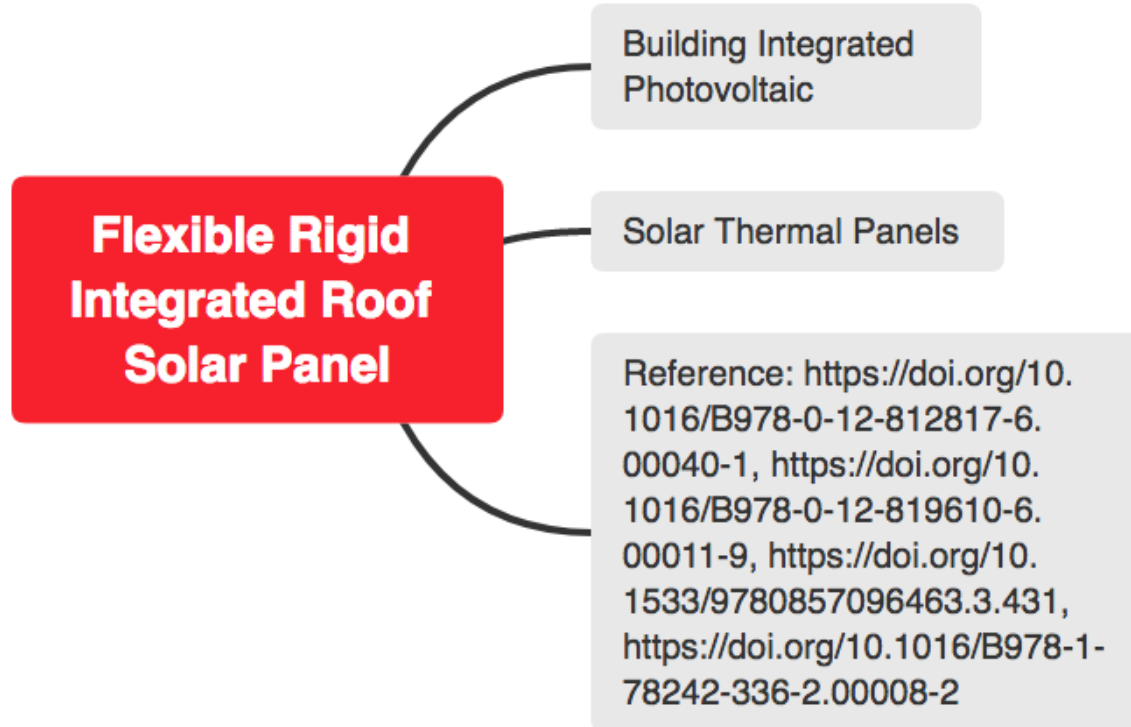

Figure 36: This mindmap discusses factors affecting the Flexible Roof Solar Panels. [201] (2019b) Aghaei et al. (2020) Kiss (णㄹ) Ferrara et al. (2017) 


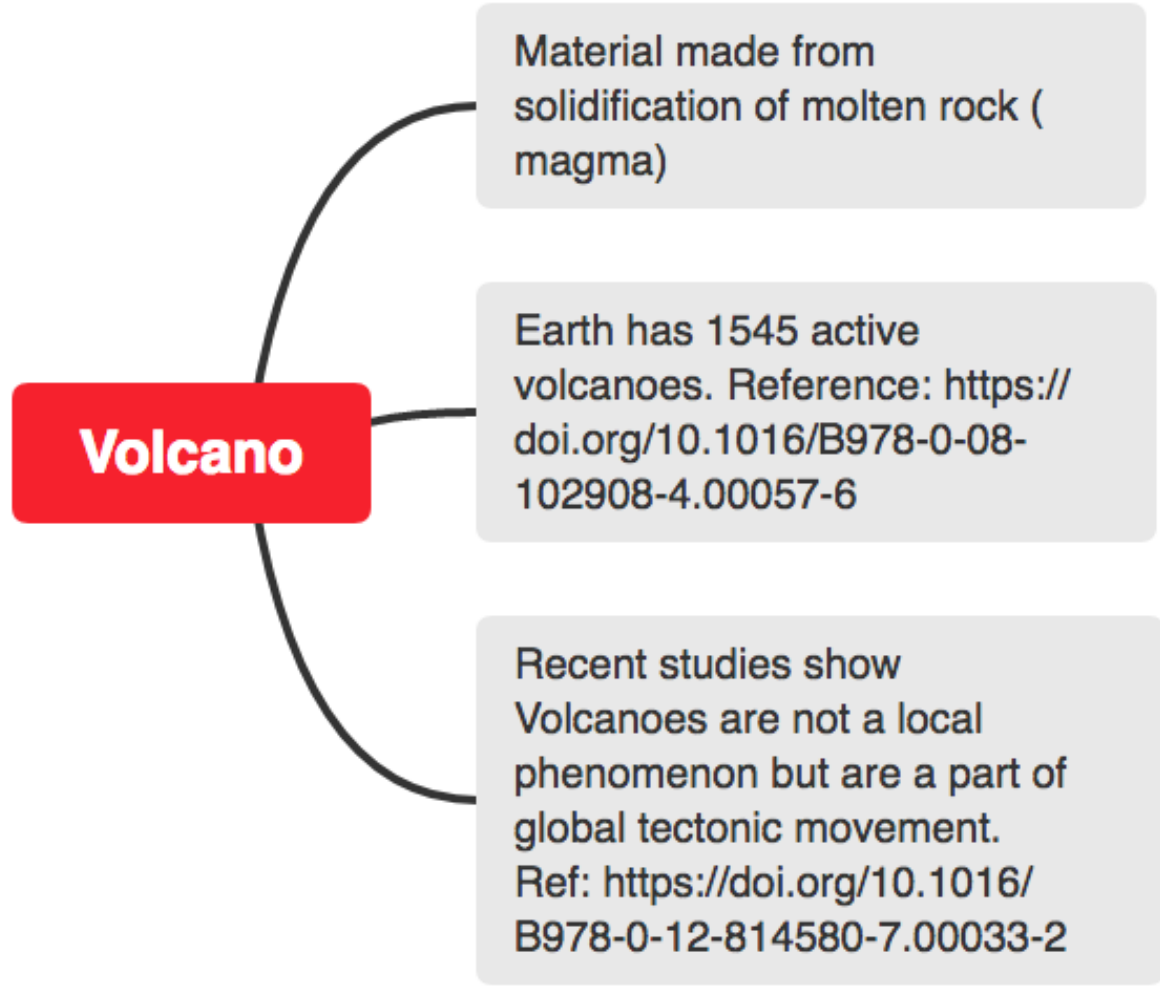

Figure 37: This mindmap discusses Volcanoes. Mccall (2010.5) Blake (201) Ban et all (2010) alohar (2018)

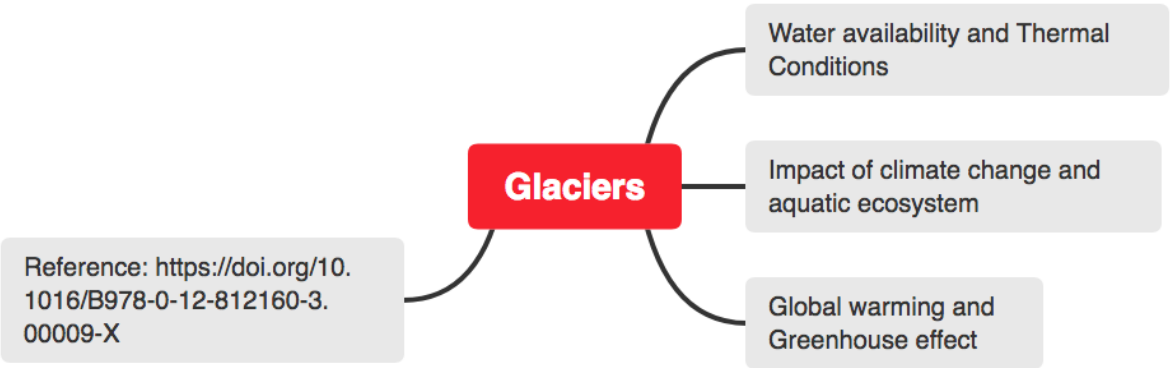

Figure 38: This mindmap discusses Glaciers. Finwlen (20113) Ninawe et al (खण18) 


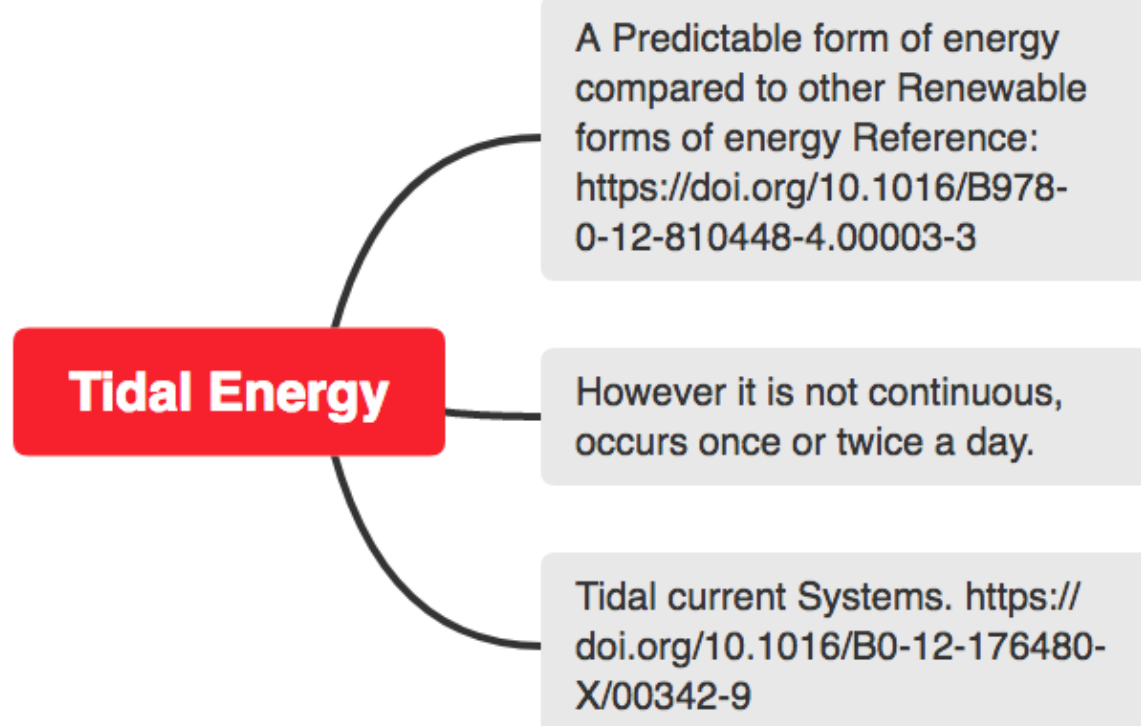

Figure 39: This mindmap discusses Tidal Energy. Neill and Hashemil (2018) Bryden (2004) 


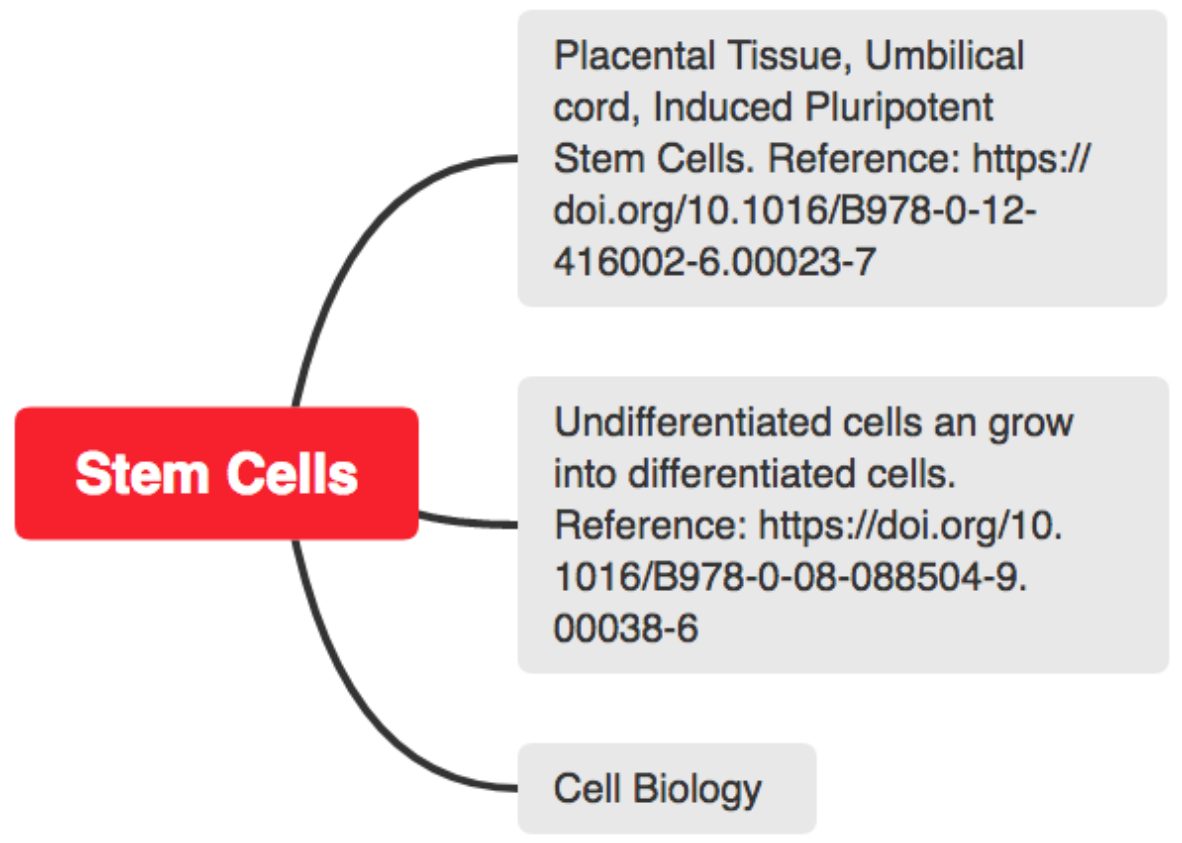

Figure 40: This mindmap discusses Stem Cells. Das and Tyagi (2014) Oh and Choo (2011)

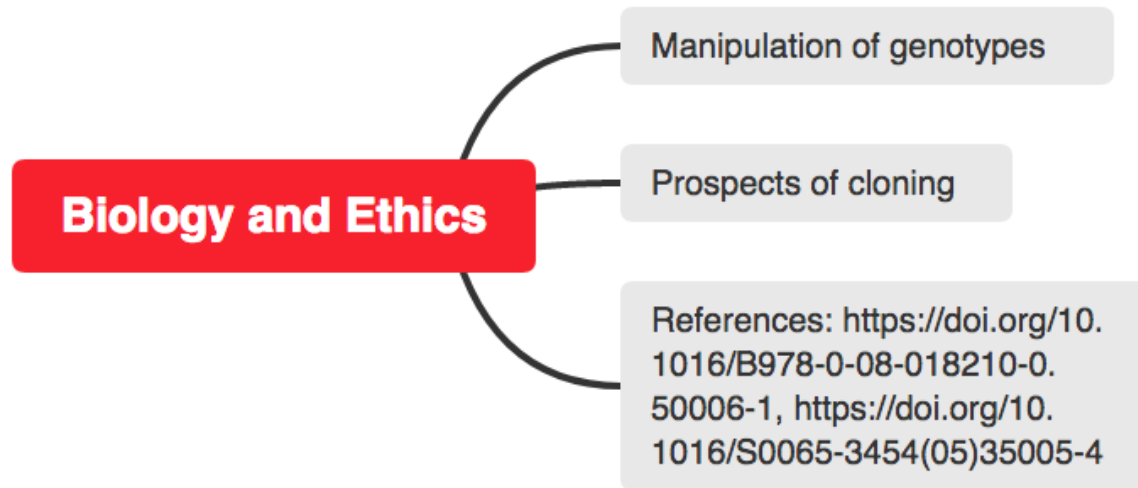

Figure 41: This mindmap discusses Biology and Ethics. Lerner (1975) Bateson (2005) 


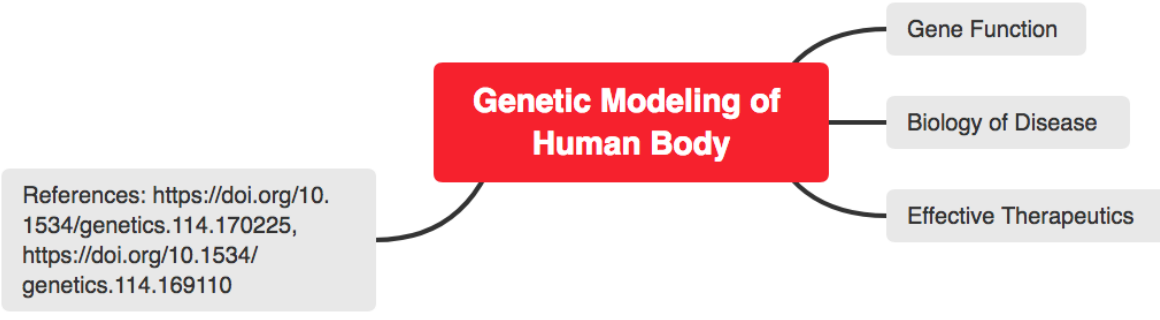

Figure 42: This mindmap discusses Genetic Modeling. Wohnston (2014) Bellen (2014)

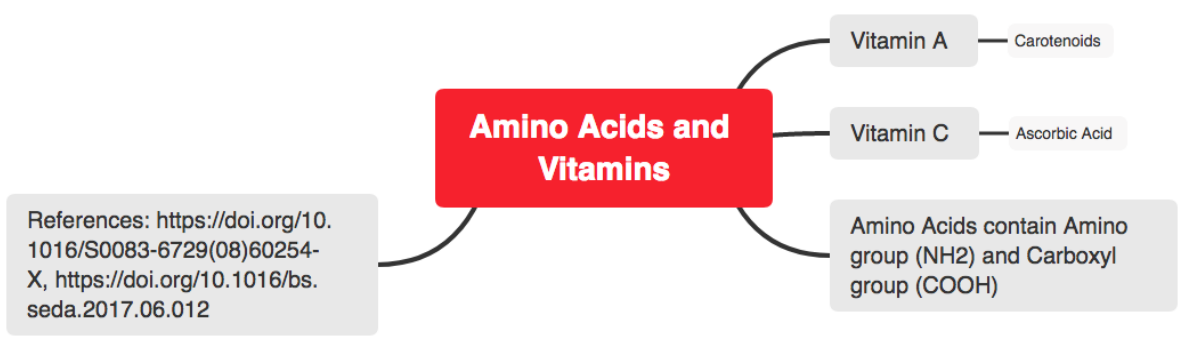

Figure 43: This mindmap discusses Amino Acids and Vitamins. Mitchell (II943) Al-Dahin et all. (2017)

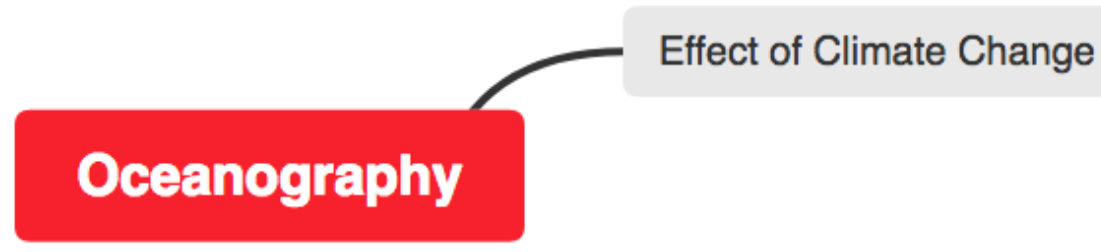

Figure 44: This mindmap discusses Oceanography. Pinsky and Selden (2017) Wilson et al $(2009)$ 


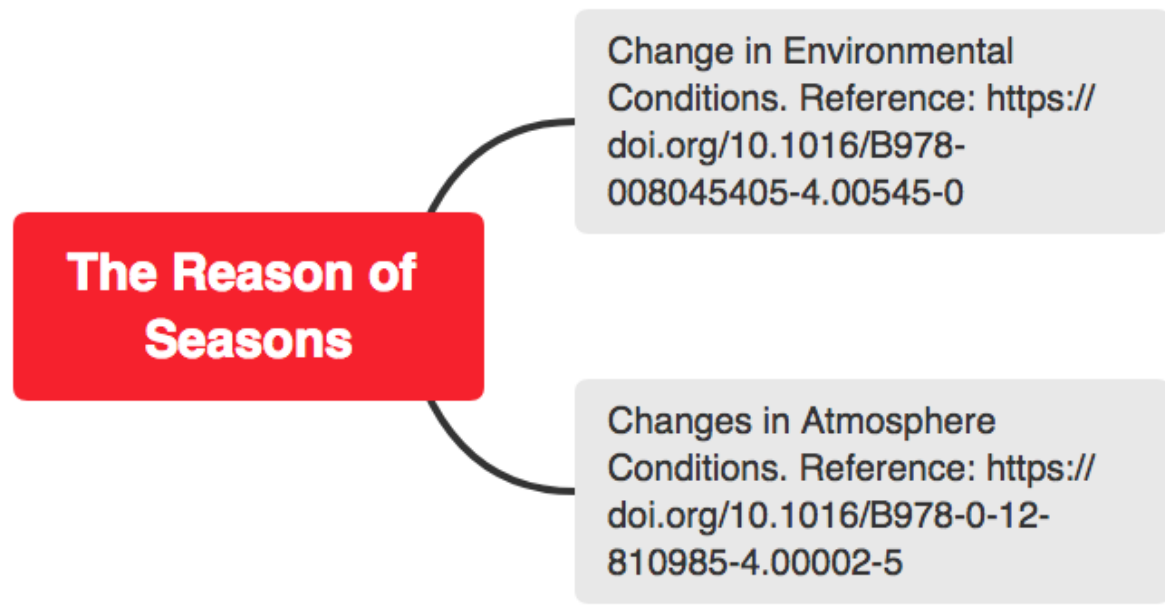

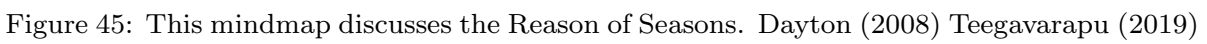

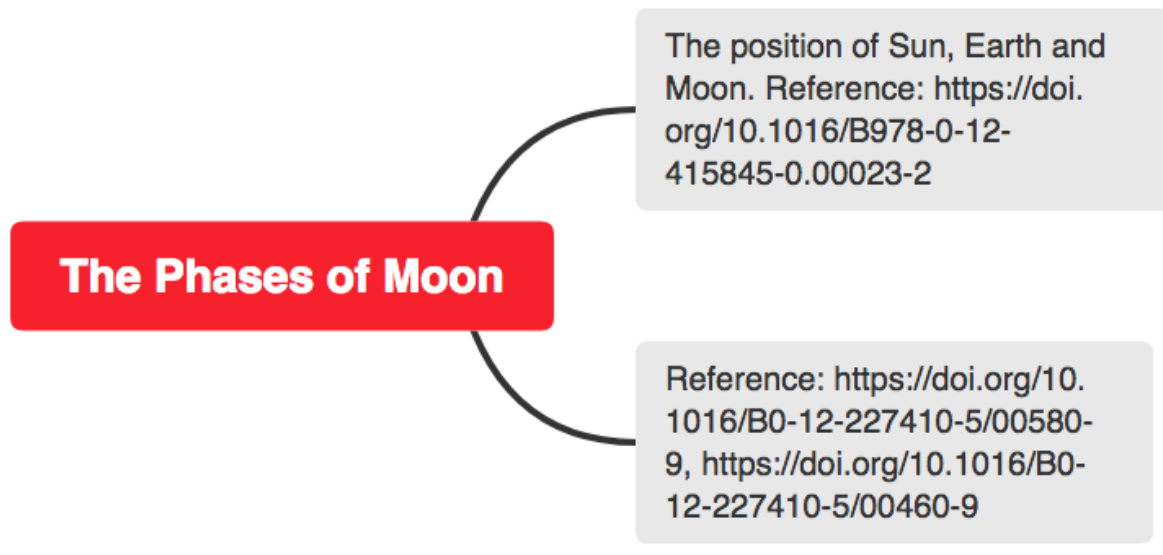

Figure 46: This mindmap discusses the Phases of Moon. Hiesinger and Jaumann (2014) Buratt.1 (2003b) Buratt.1 (2003a) 


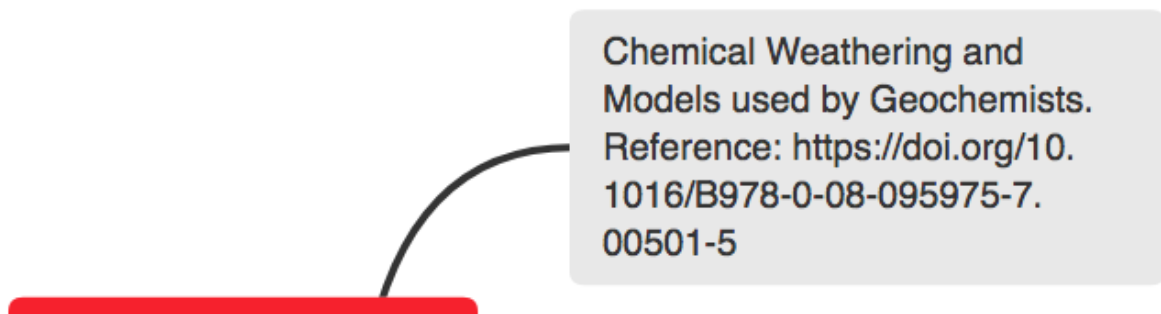

\section{Soil Formation}

Figure 47: This mindmap discusses Soil Formation. Amundson (2014) Hillel (2008)

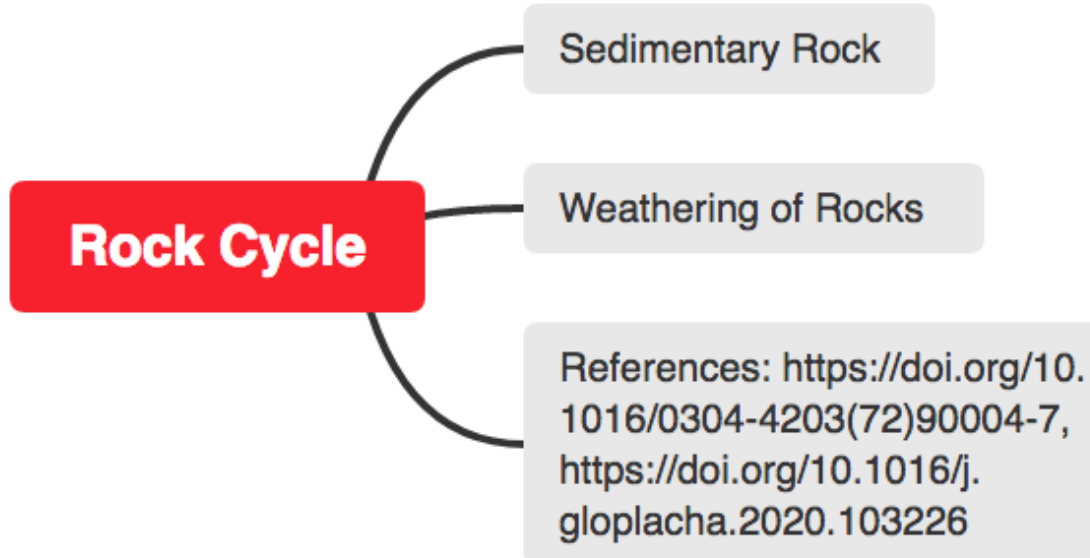

Figure 48: This mindmap discusses Rock Cycle. Garrels and Mackenzie ([1972) LechugaCrespo et al. (20201) 


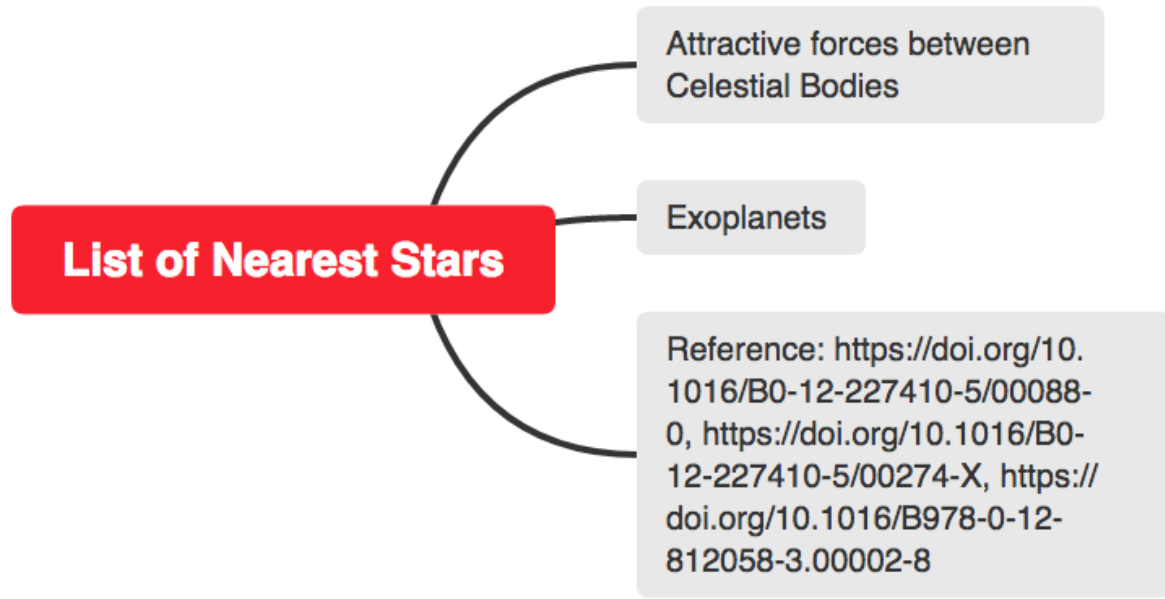

Figure 49: This mindmap discusses List of Nearest Stars. Shore (2010.3) Stacy and Vestrand (2003) Makishima (2017)

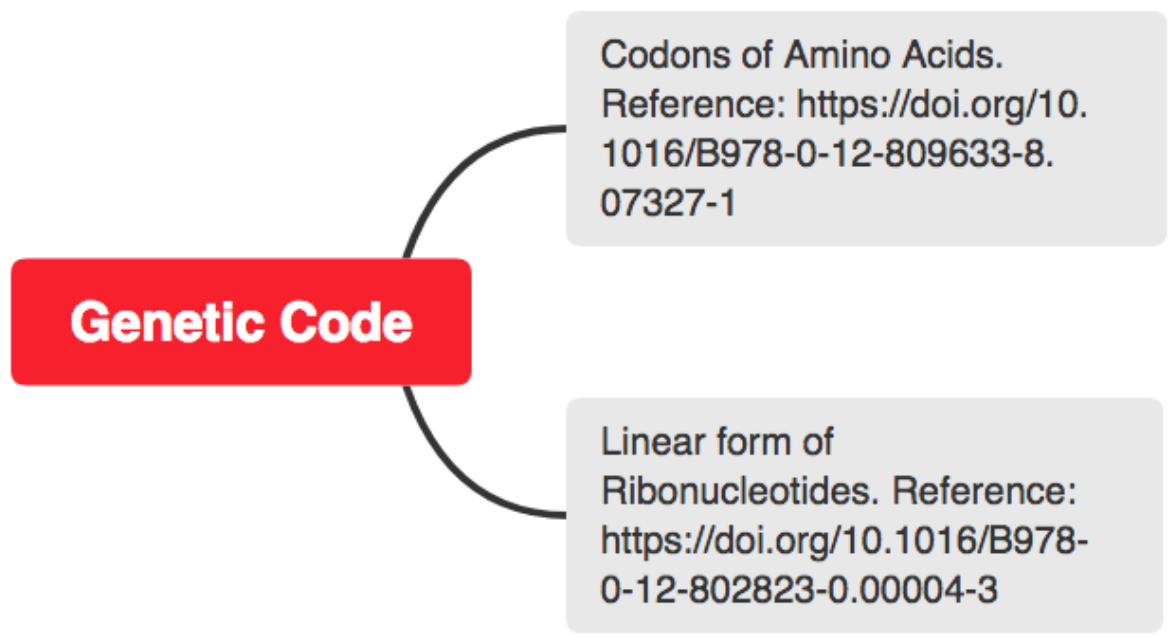

Figure 50: This mindmap discusses Genetic Code. Rodin and Branciamore (खणI7) Shen (खण19) 
Wave Function and Probability Density. Reference: https://doi. org/10.1016/B0-12-227410-5/ 00624-4

\section{Quantum Chemistry}

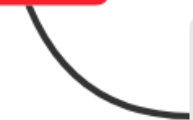

Application of large Molecular Systems. Reference: https:// doi.org/10.1016/S0065-3276( 10)59001-4

Figure 51: This mindmap discusses Quantum Chemistry. Kouril (2003) Til and Laaksonen (एण10)

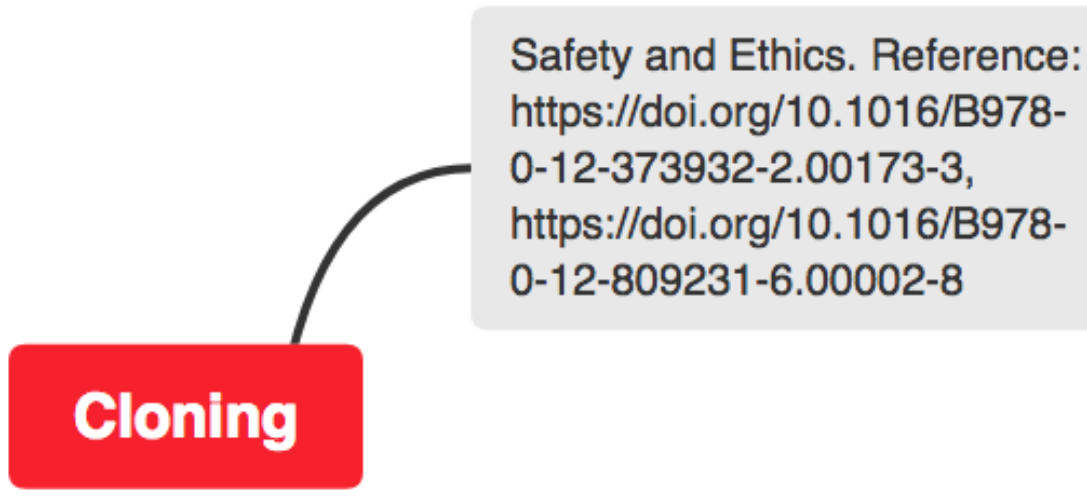

Figure 52: This mindmap discusses Cloning. Takala (2012) Nambisan (सण7]) 


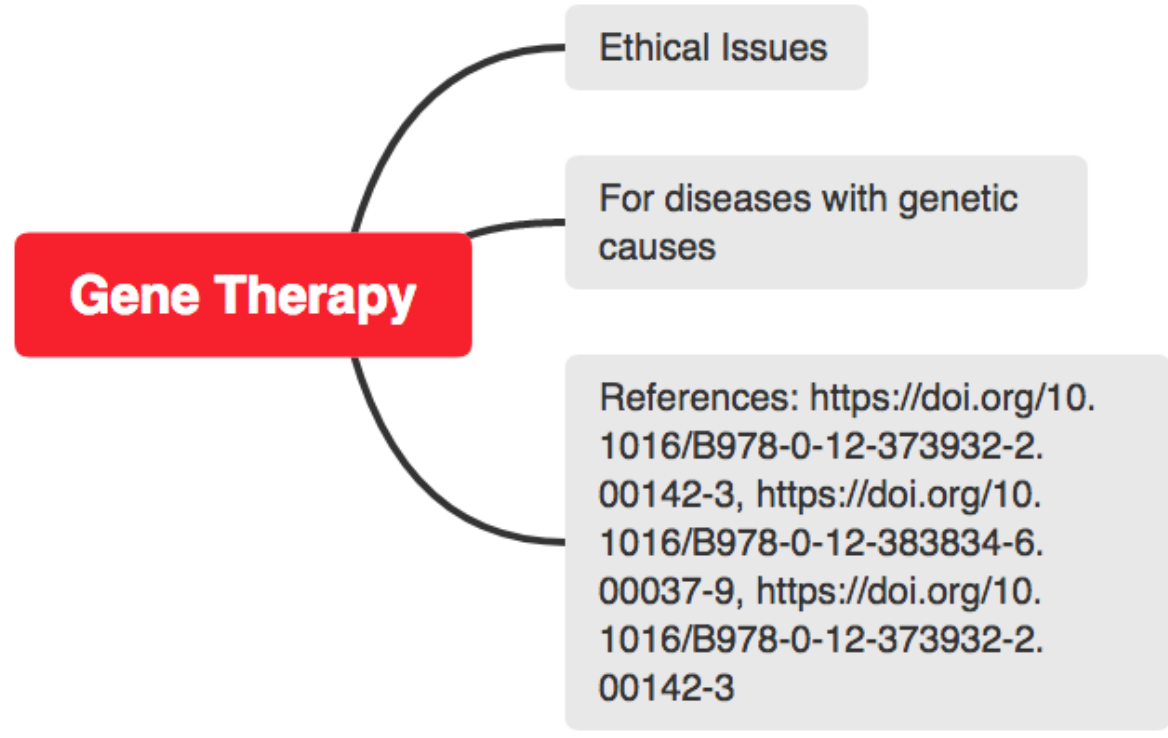

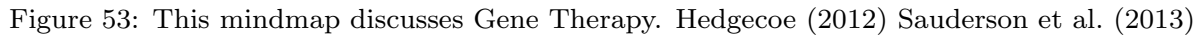

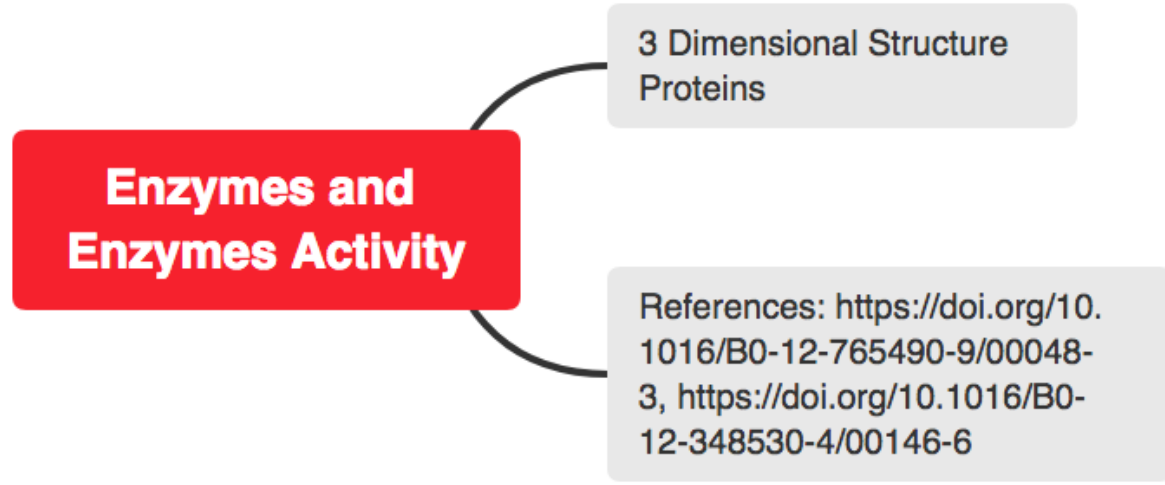

Figure 54: This mindmap discusses Enzymes and Enzymes Activity. Mares et al. (2004) Dick and Kandeler (2005) 


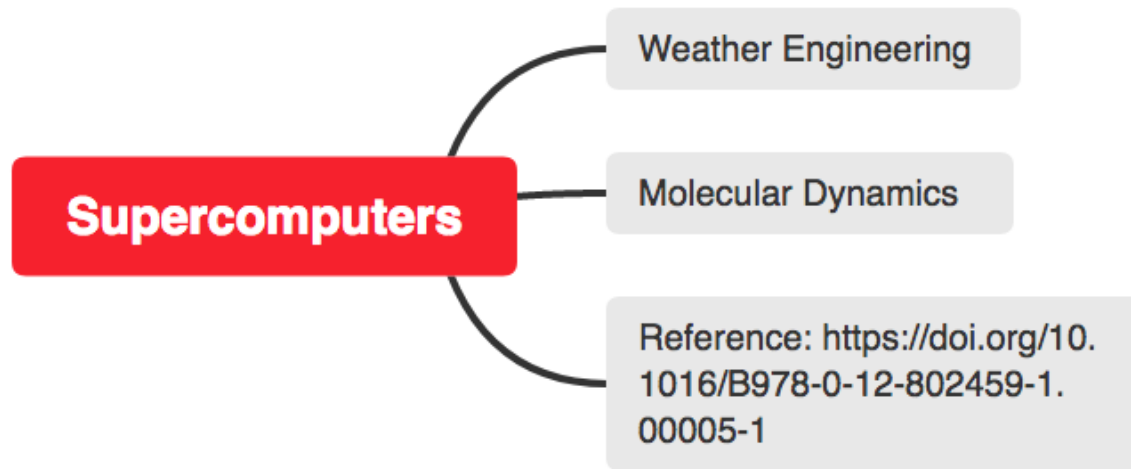

Figure 55: This mindmap discusses Supercomputers. Gioiosa (2017)

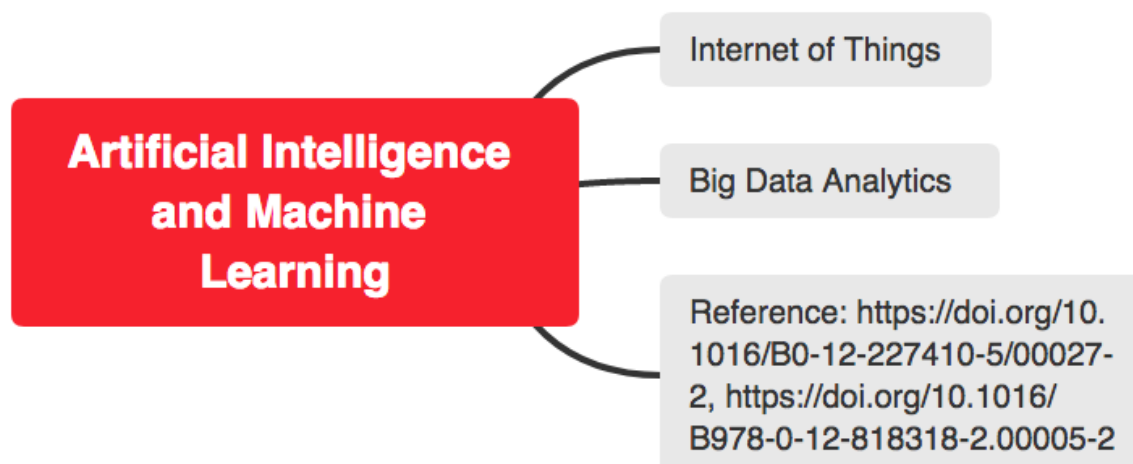

Figure 56: This mindmap discusses Artificial Intelligence and Machine Learning. Kurfess (2003) Banerjee et al. (2020)

\section{Reference Details}

Reference Details.

1. Business model canvas by Alex Osterwalder - https://www.strategyzer.com/canvas

2. Canvanizer - https://canvanizer.com

3. Fishbone diagrams were made in Microsoft Excel.

4. Mindmaps were made in Xmind - https://xmind.works/\#/ 
5. Fishbone - https://osf.io/cra85/

1. https://www.energy.gov/eere/fuelcells/hydrogen-storage-challenges

2. Hybrid fuel cell based gas turbine with turboexpander. Golchoobian et al. (2019)

3. Renewable energy sources. Murty (2017) Ghiani and Pisano (2018) Nitsch et al. (20104)

4. Smart Home Technologies. Li et al (2018) Wilson et al (2017) Alaa et aL (2017) Li and Yu (2011)

5. Precast and Prestressed Concrete. Hemalatha et al (2II2I) Madhkhan et all (2012)

6. Water Treatment Plants. Sanderson et al. (2019) Kendall et al. (2014) Waseem et all. (2020)

7. Flue Gas Treatment. Miller (2005) Audibert (2006) Miller (2010)

8. Desalination water treatment plants. Kabay et al. (2016) Kress (2019) Gray et al. (2011)

9. Retrofitting and Strengthening of industrial buildings. Wang (2018) Pipinato and Brhwiler (2016)

10. Vertical and Horizontal tunneling. Godwin and Eiscandon (2016) Ma et al. (2021) Shrestha and Panthil (2015) Liu et al. (2017)

11. Gas insulated Substations. Nagarsheth and Singh (2014) Farag et al. (11.997)

12. Condition monitoring of Substations. Liul (20201) Attoul and Ahmed (20019) Li et al. (2019) Bayliss and Hardy (2012)

13. Energy storage systems for urban Substations. Das et al. (2018) Beaudin et al. (2015)

14. Solar Power Plants. Wang (2019) Gils et al. (2017)

15. Coal Desulphurizer Plant. Zhang (2019) Speight (2019) Ors et al (11991)

16. Coal Gasification. Wagner et al. (2008) 20101 (2019a) Lin et al. (2004)

17. Dredging system for marine, reservoir, river and canal silt removal. Jeppesen et al. (200.9) Vivian and Murray (200.9) Lembil (2003) 
18. Flexible Rigid Integrated Roof Solar Panel. 2010 (2019b) Aghaei et al.

19. Volcano. McCall (2005) Blake (2021) Ran et al. (2019) alohar (2018)

20. Glaciers. Fowler (2003) Ninawe et al. (2018)

21. Tidal Energy. Neill and Hashemi (2018) Bryden (2004)

22. Stem Cells. Das and Tyagi (2014) Oh and Chon (201I)

23. Biology and Ethics. Lerner (11975) Bateson (2005)

24. Genetic Modeling of Human Body. Tohnston (2014) Bellen (2014)

25. Amino Acids and Vitamins. Mitchell (11943) Al-Dahir et al. (2017)

26. Oceanography. Pinsky and Selden (2017) Wilson et al. (2010.9)

27. The Reason of Seasons. Dayton (20108) Teegavarapu (2019)

, 2016. Colophony, in: Aronson, J. (Ed.), Meyler's Side Effects of Drugs (Sixteenth Edition). sixteenth edition ed.. Elsevier, Oxford, 


pp. 558-559. URL: https://www.sciencedirect.com/science/
article/pii/B9780444537171000573, doi:https://doi.org/10.1016/
B978-0-444-53717-1.0005/-3.
2019a. Chapter 5.3.2 - application of hydrogen combustion for elec-
trical and motive power generation, in: de Miranda, P.E.V. (Ed.),
Science and Engineering of Hydrogen-Based Energy Technologies. Aca-
demic Press, pp. 259-278. URL: https://www.sciencedirect.com/
science/article/pii/B9780128142516000058, doi:https://doi.org/10.
1016/B978-0-12-814251-6.00005-8.

, 2019b. Chapter 7 - high efficiency plants and building integrated renewable energy systems, in: Asdrubali, F., Desideri, U. (Eds.), Handbook of Energy Efficiency in Buildings. ButterworthHeinemann, pp. 441-595. URL: https://www.sciencedirect.com/ science/article/pii/B9780128128176000401, doi:https://doi.org/10. 1016/B978-0-12-812817-6.00040-1.

Abdollahi, M., Hosseini, A., 2014. Formaldehyde, in: Wexler, P. (Ed.), Encyclopedia of Toxicology (Third Edition). third edition ed.. Academic Press, Oxford, pp. 653-656. URL: https://wWw.sciencedirect.com/ science/article/pii/B9780123864543003882, doi:https://doi.org/10. 1016/B978-0-12-386454-3.00388-2.

Aghaei, M., Ebadi, H., de Oliveira, A.K.V., Vaezi, S., Eskandari, A., Castan, J.M., 2020. Chapter 11 - new concepts and applications of solar pv systems, 355 in: Gorjian, S., Shukla, A. (Eds.), Photovoltaic Solar Energy Conversion. Academic Press, pp. 349-390. URL: https://wWw.sciencedirect.com/ science/article/pii/B9780128196106000119, doi:https://doi.org/10. 1016/B978-0-12-819610-6.00011-9.

Al-Dahir, S., Vithlani, N., Smith, A., Davis, J.F., Sirohi, S., 2017. Chap360 ter 30 - vitamins, amino acids and drugs and formulations used in nutrition, in: Ray, S.D. (Ed.), A Worldwide Yearly Survey of New Data in Ad- 
verse Drug Reactions. Elsevier. volume 39 of Side Effects of Drugs Annual, pp. 345-358. URL: https://www.sciencedirect.com/science/article/ pii/S0378608017300144, doi:https://doi.org/10.1016/bs.seda.2017. 06.012 .

Alaa, M., Zaidan, A., Zaidan, B., Talal, M., Kiah, M., 2017. A review of smart home applications based on internet of things. Journal of Network and Computer Applications 97, 48-65. URL: https: //wWW.sciencedirect.com/science/article/pii/S1084804517302801, doi:https://doi.org/10.1016/j.jnca.2017.08.017.

Amundson, R., 2014. 7.1 - soil formation, in: Holland, H.D., Turekian, K.K. (Eds.), Treatise on Geochemistry (Second Edition). second edition ed.. Elsevier, Oxford, pp. 1-26. URL: https://www.sciencedirect.com/ science/article/pii/B9780080959757005015, doi:https://doi.org/10. 1016/B978-0-08-095975-7.00501-5.

Attou, A.K., Ahmed, Q., 2009. Asset management practices at qatargas, in: Alfadala, H.E., Rex Reklaitis, G., El-Halwagi, M.M. (Eds.), Proceedings of the 1st Annual Gas Processing Symposium. Elsevier, Amsterdam. volume 1 of Advances in Gas Processing, pp. 286-296. URL: https:// WWW.sciencedirect.com/science/article/pii/B9780444532923500365, doi:https://doi.org/10.1016/B978-0-444-53292-3.50036-5.

Audibert, F., 2006. Chapter 5 - combustion of waste engine oil with or without other fuels, in: Audibert, F. (Ed.), Waste Engine Oils. Elsevier, Amsterdam, pp. 199-245. URL: https://wWw.sciencedirect.com/ science/article/pii/B9780444522023500266, doi:https://doi.org/10. 1016/B978-044452202-3/50026-6.

Banerjee, A., Chakraborty, C., Kumar, A., Biswas, D., 2020. Chapter 5 emerging trends in iot and big data analytics for biomedical and health care technologies, in: Balas, V.E., Solanki, V.K., Kumar, R., Khari, M. (Eds.), Handbook of Data Science Approaches for Biomedical Engineering. 
Academic Press, pp. 121-152. URL: https://www.sciencedirect.com/ science/article/pii/B9780128183182000052, doi:https://doi.org/10. 1016/B978-0-12-818318-2.00005-2.

Bateson, P., 2005. Ethics and behavioral biology, Academic Press. vol-

Bryden, I.G., 2004. Tidal energy, in: Cleveland, C.J. (Ed.), Encyclopedia of Energy. Elsevier, New York, pp. 139-150. URL: nttps: 
//WWW.sciencedirect.com/science/article/pii/B012176480X003429, doi:https://doi.org/10.1016/B0-12-176480-X/00342-9.

Brschweiler, B.J., Merlot, C., 2017. Azo dyes in clothing textiles can be cleaved into a series of mutagenic aromatic amines which are not regulated yet. Regulatory Toxicology and Pharmacology 88, 214-226. URL: https://wWW.sciencedirect.com/science/article/ pii/S0273230017301812, doi:https://doi.org/10.1016/j.yrtph.2017. 06.012 .

Buratti, B.J., 2003a. Moon, in: Meyers, R.A. (Ed.), Encyclopedia of Physical Science and Technology (Third Edition). third edition ed.. Academic Press, New York, pp. 161-172. URL: https: //WWW.sciencedirect.com/science/article/pii/B0122274105004609, doi:https://doi.org/10.1016/B0-12-227410-5/00460-9.

Buratti, B.J., 2003b. Planetary satellites, natural, in: Meyers, R.A. (Ed.), Encyclopedia of Physical Science and Technology (Third Edition). third edition ed.. Academic Press, New York, pp. 329-355. URL: https: //wWW.sciencedirect.com/science/article/pii/B0122274105005809, doi:https://doi.org/10.1016/B0-12-227410-5/00580-9.

Casero, I., Sicilia, D., Rubio, S., Prez-Bendito, D., 1997. Chemical degradation of aromatic amines by fenton's reagent. Water Research 31, 1985-1995. URL: https://wWW.sciencedirect.com/science/article/ pii/S0043135496003442, doi:https://doi.org/10.1016/S0043-1354(96) $00344-2$.

Das, B.C., Tyagi, A., 2014. Chapter 23 - stem cells: A trek from laboratory to clinic to industry, in: Verma, A.S., Singh, A. (Eds.), Animal Biotechnology. Academic Press, San Diego, pp. 425-450. URL: https:// WWW.sciencedirect.com/science/article/pii/B9780124160026000237, doi:https://doi.org/10.1016/B978-0-12-416002-6.00023-7. 
Das, C.K., Bass, O., Kothapalli, G., Mahmoud, T.S., Habibi, D., 2018. Overview of energy storage systems in distribution networks: Placement, sizing, operation, and power quality. Renewable and Sustainable Energy Reviews 91, 12051230. URL: https://www.sciencedirect.com/science/article/pii/ S1364032118301606, doi:https://doi.org/10.1016/j.rser.2018.03.068.

Dayton, G., 2008. Seasonality, in: Jrgensen, S.E., Fath, B.D. (Eds.), Encyclopedia of Ecology. Academic Press, Oxford, pp. 3168-3171. URL: https:// WwW.sciencedirect.com/science/article/pii/B9780080454054005450, doi:https://doi.org/10.1016/B978-008045405-4.00545-0.

Dick, R., Kandeler, E., 2005. Enzymes in soils, in: Hillel, D. (Ed.), Encyclopedia of Soils in the Environment. Elsevier, Oxford, pp. 448-456. URL: https: //wWw.sciencedirect.com/science/article/pii/B0123485304001466, doi:https://doi.org/10.1016/B0-12-348530-4/00146-6.

Elder, T., 2004. Non-wood products - chemicals from wood, in: Burley, J. (Ed.), Encyclopedia of Forest Sciences. Elsevier, Oxford, pp. 607612. URL: https://www.sciencedirect.com/science/article/pii/ B01214b160/000b/0, doi:https://doi.org/10.1016/B0-12-145160-7/ $00057-0$.

Farag, A., Cheng, T., Hu, L., Penn, D., Thompson, J., 1997. Study for optimal design of gas insulated substations (gis) to reduce magnetic fields. International Journal of Electrical Power Energy Systems 19, 185-194. URL: https://www.sciencedirect.com/science/article/ pii/S0142061596000464, doi:https://doi.org/10.1016/S0142-0615(96) 00046-4.

Ferrara, C., Wilson, H., Sprenger, W., 2017. 8 - building-integrated photovoltaics (bipv), in: Pearsall, N. (Ed.), The Performance of Photovoltaic (PV) Systems. Woodhead Publishing, pp. 235-250. URL: https:// WWw.sciencedirect.com/science/article/pii/B9781782423362000082, doi:https://doi.org/10.1016/B978-1-78242-336-2.00008-2. 
Fowler, A., 2003. Glaciers, in: Holton, J.R. (Ed.), Encyclopedia of Atmospheric Sciences. Academic Press, Oxford, pp. 869-875. URL: https: //wWW.sciencedirect.com/science/article/pii/B0122270908001585, doi:https://doi.org/10.1016/B0-12-227090-8/00158-5.

Garrels, R.M., MacKenzie, F.T., 1972. A quantitative model for the sedimentary rock cycle. Marine Chemistry 1, 27-41. URL: https://www.sciencedirect. com/science/article/pii/0304420372900047, doi:https://doi.org/10. 1016/0304-4203(72)90004-7.

485 Gennaro, M., Bertolo, P., Marengo, E., 1990. Determination of aromatic amines at trace levels by ion interaction reagent reversedphase high-performance liquid chromatography: Analysis of hair dyes and other water-soluble dyes. Journal of Chromatography A 518, 149-156. URL: https://www.sciencedirect.com/science/article/ pii/S002196730193170X, doi:https://doi.org/10.1016/S0021-9673(01) $93170-\mathrm{X}$.

Ghiani, E., Pisano, G., 2018. Chapter 2 - impact of renewable energy sources and energy storage technologies on the operation and planning of smart distribution networks, in: Zare, K., Nojavan, S. (Eds.), Operation of Distributed Energy Resources in Smart Distribution Networks. Academic Press, pp. 25-48. URL: https://www.sciencedirect.com/ science/article/pii/B9780128148914000023, doi:https://doi.org/10. 1016/B978-0-12-814891-4.00002-3.

Gils, H.C., Scholz, Y., Pregger, T., Luca de Tena, D., Heide, D., 2017. Integrated modelling of variable renewable energy-based power supply in europe. Energy 123, 173-188. URL: https://www.sciencedirect.com/science/article/ pii/S0360544217301238, doi:https://doi.org/10.1016/j.energy.2017. 01.115 .

Gioiosa, R., 2017. Chapter 5 - resilience for extreme scale computing, in: Vega, A., Bose, P., Buyuktosunoglu, A. (Eds.), Rugged Embedded Systems. Morgan 
Kaufmann, Boston, pp. 123-148. URL: https://www.sciencedirect.com/ science/article/pii/B9780128024591000051, doi:https://doi.org/10. 1016/B978-0-12-802459-1.00005-1.

Godwin, W.H., Escandon, R., 2016. Tunnels. Springer International Publishing, Cham. pp. 1-11. URL: https://doi.org/10.1007/978-3-319-12127-7_ 287-1, doi:10.1007/978-3-319-12127-7_287-1.

Golchoobian, H., Taheri, M.H., Saedodin, S., 2019. Thermodynamic analysis of turboexpander and gas turbine hybrid system for gas pressure reduction station of a power plant. Case Studies in Thermal Engineering 14, 100488. URL: https://www.sciencedirect.com/science/article/ pii/S2214157X19300632, doi:https://doi.org/10.1016/j.csite.2019. 100488.

Gray, S., Semiat, R., Duke, M., Rahardianto, A., Cohen, Y., 2011. 4.04 seawater use and desalination technology, in: Wilderer, P. (Ed.), Treatise on Water Science. Elsevier, Oxford, pp. 73-109. URL: https:// WWw.sciencedirect.com/science/article/pii/B9780444531995000774, doi:https://doi.org/10.1016/B978-0-444-53199-5.00077-4.

Hedgecoe, A., 2012. Gene therapy, in: Chadwick, R. (Ed.), Encyclopedia of Applied Ethics (Second Edition). second edition ed.. Academic Press, San Diego, pp. 407-413. URL: https://www.sciencedirect.com/ science/article/pii/B9780123739322001423, doi:https://doi.org/10. 1016/B978-0-12-373932-2.00142-3.

Hemalatha, K., James, C., Natrayan, L., Swamynadh, V., 2021. Analysis of rcc t-beam and prestressed concrete box girder bridges super structure under different span conditions. Materials Today: Proceedings 37, 1507-1516. URL: https://www.sciencedirect.com/science/article/ pii/S2214785320352093, doi:https://doi.org/10.1016/j.matpr.2020. 07.119. international Conference on Newer Trends and Innovation in Mechanical Engineering: Materials Science. 
Hiesinger, H., Jaumann, R., 2014. Chapter 23 - the moon, in: Spohn, T., Breuer, D., Johnson, T.V. (Eds.), Encyclopedia of the Solar System (Third Edition). third edition ed.. Elsevier, Boston, pp. 493-538. URL: https:// WWW.sciencedirect.com/science/article/pii/B9780124158450000232, doi:https://doi.org/10.1016/B978-0-12-415845-0.00023-2.

Hillel, D., 2008. 3. - soil formation, in: Hillel, D. (Ed.), Soil in the Environment. Academic Press, San Diego, pp. 15-26. URL: https:// WWW.sciencedirect.com/science/article/pii/B9780123485366500083, doi:https://doi.org/10.1016/B978-0-12-348536-6.50008-3.

Huang, B., Lei, C., Wei, C., Zeng, G., 2014. Chlorinated volatile organic compounds (cl-vocs) in environment sources, potential human health impacts, and current remediation technologies. Environment International 71, 118-138. URL: https://www.sciencedirect.com/science/article/ pii/S0160412014001974, doi:https://doi.org/10.1016/j.envint.2014. 06.013.

Hubbe, M., 2004. Pulping - chemical additives, in: Burley, J. (Ed.), Encyclopedia of Forest Sciences. Elsevier, Oxford, pp. 933-939. URL: https: //WWW.sciencedirect.com/science/article/pii/B0121451607001356, doi:https://doi.org/10.1016/B0-12-145160-7/00135-6.

Jeppesen, E., Sndergaard, M., Jensen, H., Ventla, A.M., 2009. Lake and reservoir management, in: Likens, G.E. (Ed.), Encyclopedia of Inland Waters. Academic Press, Oxford, pp. 295-309. URL: https://www.sciencedirect.com/ science/article/pii/B9780123706263002453, doi:https://doi.org/10. 1016/B978-012370626-3.00245-3.

Johnston, M., 2014. Humans as a model organism: The time is now. Genetics 198, 441-441. URL: https://wWw.genetics. org/content/198/2/441, doi:10.1534/genetics.114.170225, arXiv:https://www.genetics.org/content/198/2/441.full.pdf. 
Kabay, N., zgr Arar, Bunani, S., 2016. Chapter 8 - water treatment by electromembrane processes, in: Hankins, N.P., Singh, R. (Eds.), Emerging Membrane Technology for Sustainable Water Treatment. Elsevier, Boston, pp. 181-214. URL: https://wwW.sciencedirect.com/ science/article/pii/B9780444633125000085, doi:https://doi.org/10. 1016/B978-0-444-63312-5.00008-5.

Kendall, C., Doctor, D., Young, M., 2014. 7.9 - environmental isotope applications in hydrologic studies, in: Holland, H.D., Turekian, K.K. (Eds.), Treatise on Geochemistry (Second Edition). second edition ed.. Elsevier, Oxford, pp. 273-327. URL: https://wwW.sciencedirect.com/ science/article/pii/B9780080959757005106, doi:https://doi.org/10. 1016/B978-0-08-095975-7.00510-6.

Kiss, G., 2012. 19 - solar energy in the built environment: powering the sustainable city, in: Zeman, F. (Ed.), Metropolitan Sustainability. Woodhead Publishing. Woodhead Publishing Series in Energy, pp. 431-456. URL: https://wWW.sciencedirect.com/science/article/pii/ B9/8085/090461500199, doi:https://doi.org/10.1533/9780857096463. 3.431 .

Kouri, D.J., 2003. Quantum chemistry, in: Meyers, R.A. (Ed.), Encyclopedia of Physical Science and Technology (Third Edition). third edition ed.. Academic Press, New York, pp. 301-317. URL: https: //wWw.sciencedirect.com/science/article/pii/B0122274105006244, doi:https://doi.org/10.1016/B0-12-227410-5/00624-4.

Kress, N., 2019. Chapter 1 - introduction, in: Kress, N. (Ed.), Marine Impacts of Seawater Desalination. Elsevier, pp. 1-10. URL: https:// WWW.sciencedirect.com/science/article/pii/B9780128119532000013, doi:https://doi.org/10.1016/B978-0-12-811953-2.00001-3.

590 Kurfess, F.J., 2003. Artificial intelligence, in: Meyers, R.A. (Ed.), Encyclopedia of Physical Science and Technology (Third Edition). third 
edition ed.. Academic Press, New York, pp. 609-629. URL: https: //WWW.sciencedirect.com/science/article/pii/B0122274105000272, doi:https://doi.org/10.1016/B0-12-227410-5/00027-2.

Lechuga-Crespo, J., Snchez-Prez, J., Sauvage, S., Hartmann, J., Amiotte Suchet, P., Probst, J., Ruiz-Romera, E., 2020. A model for evaluating continental chemical weathering from riverine transports of dissolved major elements at a global scale. Global and Planetary Change 192, 103226. URL: https://www.sciencedirect.com/science/article/pii/ S09218181203011/X, doi:https://doi.org/10.1016/j.gloplacha.2020. 103226.

Lembi, C.A., 2003. 24 - control of nuisance algae, in: WEHR, J.D., SHEATH, R.G. (Eds.), Freshwater Algae of North America. Academic Press, Burlington. Aquatic Ecology, pp. 805-834. URL: https://wWw. sciencedirect.com/ science/article/pii/B9780127415505500258, doi:https://doi.org/10. 1016/B978-012741550-5/50025-8.

Lerner, I.M., 1975. Chapter 2 - ethics and the new biology, in: Birch, C., Abrecht, P. (Eds.), Genetics and the Quality of Life. Pergamon, pp. 20-35. URL: https://wWW.sciencedirect.com/ science/article/pii/B9780080182100500061, doi:https://doi.org/10. 1016/B978-0-08-018210-0.50006-1.

Li, B., Yu, J., 2011. Research and application on the smart home based on component technologies and internet of things. Procedia Engineering 15, 2087-2092. URL: https://www.sciencedirect.com/science/article/ pii/S1877705811018911, doi:https://doi.org/10.1016/j.proeng.2011. 08.390. cEIS 2011.

Li, J., Huang, Q., Li, P., Huang, H., Zhang, L., 2019. Chapter 8 - intelligent status monitoring system for smart substations, in: Yuan, Y., Yang, Y. (Eds.), IEC 61850-Based Smart Substations. Academic Press, pp. 255-305. URL: https://www.sciencedirect.com/ 
science/article/pii/B9780128151587000081, doi:https://doi.org/10. 1016/B978-0-12-815158-7.00008-1.

Li, M., Gu, W., Chen, W., He, Y., Wu, Y., Zhang, Y., 2018. Smart home: Architecture, technologies and systems. Procedia Computer Science 131, 393-400. URL: https://www.sciencedirect.com/science/article/ pii/S1877050918305994, doi:https://doi.org/10.1016/j.procs.2018. 04.219. recent Advancement in Information and Communication Technology: .

Liu, B., Zhang, D., Fang, L., 2017. Structural response of existed metro tunnels to adjacent large-section pipe jacking construction. Procedia Engineering 189, 11-17. URL: https://wWW.sciencedirect.com/science/article/ pii/S1877705817321240, doi:https://doi.org/10.1016/j.proeng. 2017. 05.003. roceedings of the International Scientific Conference Transportation Geotechnics and Geoecology (TGG-2017).

Liu, H., 2020. Chapter 8 - rail transit inspection unmanned aerial vehicle (uav) systems, in: Liu, H. (Ed.), Robot Systems for Rail Transit Applications. Elsevier, pp. 329-386. URL: https://wwW.sciencedirect.com/ science/article/pii/B9780128229682000085, doi:https://doi.org/10. 1016/B978-0-12-822968-2.00008-5.

Liu, J., Mallett, C., Beath, A., Elsworth, D., Brady, B., 2004. A coupled flowtransport-deformation model for underground coal gasification, in: Stephanson, O. (Ed.), Coupled Thermo-Hydro-Mechanical-Chemical Processes in Geo-Systems. Elsevier. volume 2 of Elsevier Geo-Engineering Book Series, pp. 611-616. URL: https://wWw.sciencedirect.com/science/article/ pii/S1571996004801071, doi:https://doi.org/10.1016/S1571-9960(04) 80107-1.

Ma, S., Duan, Z., Shao, Y., Huang, Z., Liu, Y., Tang, X., 2021. Sheltering effect of vertical twin tunnel excavation for different horizontal distances on 
the ground and pipelines. Sdhan 46, 48. URL: https://doi.org/10.1007/ s12046-()2.1-(0156b-9, doi:10.1007/s12046-021-01565-9.

Madhkhan, M., Entezam, M., Torki, M., 2012. Mechanical properties of precast reinforced concrete slab tracks on non-ballasted foundations. Scientia Iranica 19, 20-26. URL: https://www.sciencedirect.com/science/article/ pii/S1026309811002483, doi:https://doi.org/10.1016/j.scient.2011. 11.037.

Makishima, A., 2017. Chapter 2 - formation of the proto-earth in the solar nebula, in: Makishima, A. (Ed.), Origins of the Earth, Moon, and Life. Elsevier, pp. 25-58. URL: https://wWw.sciencedirect.com/ science/article/pii/B9780128120583000028, doi:https://doi.org/10. 1016/B978-0-12-812058-3.00002-8.

Mares, D., Mrva, K., Fincher, G., 2004. Enzyme activities, in: Wrigley, C. (Ed.), Encyclopedia of Grain Science. Elsevier, Oxford, pp. 357-365. URL: https: //wWw.sciencedirect.com/science/article/pii/B0127654909000483, doi:https://doi.org/10.1016/B0-12-765490-9/00048-3.

McCall, G., 2005. Volcanoes, in: Selley, R.C., Cocks, L.R.M., Plimer, I.R. (Eds.), Encyclopedia of Geology. Elsevier, Oxford, pp. 565-579. URL: https: //wWw.sciencedirect.com/science/article/pii/B0123693969001374, doi:https://doi.org/10.1016/B0-12-369396-9/00137-4.

Miller, B.G., 2005. Chapter 6 - emissions control strategies for power plants, in: Miller, B.G. (Ed.), Coal Energy Systems. Academic Press, Burlington. Sustainable World, pp. 283-392. URL: https://www.sciencedirect.com/ science/article/pii/B9780124974517500061, doi:https://doi.org/10. 1016/B978-012497451-7/50006-1.

Miller, B.G., 2011. 9 - emissions control strategies for power plants, 675 in: Miller, B.G. (Ed.), Clean Coal Engineering Technology. ButterworthHeinemann, Boston, pp. 375-481. URL: https://www.sciencedirect.com/ 
science/article/pii/B9781856177108000091, doi:https://doi.org/10. 1016/B978-1-85617-710-8.00009-1.

Mitchell, H., 1943. The chemical and physiological relationship between vita-

mins and amino acids, Academic Press. volume 1 of Vitamins Hormones, pp. 157-194. URL: https://www.sciencedirect.com/science/article/ pii/S008367290860254X, doi:https://doi.org/10.1016/S0083-6729(08) 60)254-X.

Murty, P., 2017. Chapter 24 - renewable energy sources, in: Murty, P. (Ed.), Electrical Power Systems. Butterworth-Heinemann, Boston, pp. 783-800. URL: https://wWW.sciencedirect.com/science/ article/pii/B9780081011249000243, doi:https://doi.org/10.1016/ B.978-(0)-(08-10112.4-9.(0)(0) $24-3$.

Nagarsheth, R., Singh, S., 2014. Study of gas insulated substation and its comparison with air insulated substation. International Journal of Electrical Power Energy Systems 55, 481485. URL: https://wWW.sciencedirect.com/science/article/pii/ S(0142061513003943, doi:https://doi.org/10.1016/j.ijepes.2013.09. 012 .

Nambisan, P., 2017. Chapter 2 - cloning, in: Nambisan, P. (Ed.), An Introduction to Ethical, Safety and Intellectual Property Rights Issues in Biotechnology. Academic Press, pp. 25-53. URL: https://wWW.sciencedirect.com/ science/article/pii/B9780128092316000028, doi:https://doi.org/10. 1016/B978-0-12-809231-6.00002-8.

NEBO, M., 2005. 5 - functional sport footwear, in: Shishoo, R. (Ed.), Textiles in Sport. Woodhead Publishing. Woodhead Publishing Series in Textiles, pp. 70-85. URL: https://wWW.sciencedirect.com/ science/article/pii/B9781855739222500050, doi:https://doi.org/10. 1533/9781845690885.1.70. 
705 Neill, S.P., Hashemi, M.R., 2018. Chapter 3 - tidal energy, in: Neill, S.P., Hashemi, M.R. (Eds.), Fundamentals of Ocean Renewable Energy. Academic Press. E-Business Solutions, pp. 47-81. URL: https:// WWW.sciencedirect.com/science/article/pii/B9780128104484000033, doi:https://doi.org/10.1016/B978-0-12-810448-4.00003-3.

Ninawe, A.S., Indulkar, S.T., Amin, A., 2018. Chapter 9 - impact of climate change on fisheries, in: Singh, R.L., Mondal, S. (Eds.), Biotechnology for Sustainable Agriculture. Woodhead Publishing, pp. 257-280. URL: https:// WWW.sciencedirect.com/science/article/pii/B978012812160300009X, doi:https://doi.org/10.1016/B978-0-12-812160-3.00009-X.

715 Nitsch, J., Krewitt, W., Langniss, O., 2004. Renewable energy in europe, in: Cleveland, C.J. (Ed.), Encyclopedia of Energy. Elsevier, New York, pp. 313-331. URL: https://www.sciencedirect.com/science/article/pii/ B(017)176480X00365X, doi:https://doi.org/10.1016/B0-12-176480-X/ 0036b-X.

720 Oh, S., Choo, A., 2011. 1.25 - stem cells, in: Moo-Young, M. (Ed.), Comprehensive Biotechnology (Second Edition). second edition ed.. Academic Press, Burlington, pp. 341-365. URL: https://wWw.sciencedirect.com/ science/article/pii/B9780080885049000386, doi:https://doi.org/10. 1016/B978-0-08-088504-9.00038-6.

Ors, N., Rossi, G., Trois, P., Valenti, P., Zecchin, A., 1991. Coal biodesulfurization: design criteria of a pilot plant. Resources, Conservation and Recycling 5, 211-230. URL: https://wWw.sciencedirect. com/science/article/pii/092134499190026K, doi:https://doi.org/10. 1016/0921-3449(91)90026-K. biprocessing of fossils fuels.

730 Pinsky, M.L., Selden, R.L., 2017. Chapter 2 - climate variability, climate change, and conservation in a dynamic ocean, in: Levin, P.S., Poe, M.R. (Eds.), Conservation for the Anthropocene Ocean. Academic Press, pp. 23-38. URL: https://wWW.sciencedirect.com/ 
science/article/pii/B9780128053751000027, doi:https://doi.org/10. 1016/B978-0-12-805375-1.00002-7.

Pipinato, A., Brhwiler, E., 2016. Chapter 4 - fatigue and fracture, in: Pipinato, A. (Ed.), Innovative Bridge Design Handbook. ButterworthHeinemann, Boston, pp. 49-87. URL: https://wwW.sciencedirect.com/ science/article/pii/B9780128000588000049, doi:https://doi.org/10.

Ran, Q., Ren, D., Wang, Y., Tong, M., Sun, Y., Yan, L., Dong, J., Wang, Z., Xu, M., Li, N., Peng, H., Chen, F., Yuan, D., Xu, Q., Wang, S., Wang, Q., 2019. Chapter 4 - volcanic gas reservoir characteristics and models, in: Ran, Q., Ren, D., Wang, Y., Tong, M., Sun, Y., Yan, L., Dong, J., Wang, Z., Xu, M., Li, N., Peng, H., Chen, F., Yuan, D., Xu, Q., Wang, S., Wang, Q. (Eds.), Development of Volcanic Gas Reservoirs. Gulf Professional Publishing, pp. 267-341. URL: https://wwW.sciencedirect.com/ science/article/pii/B9780128161326000041, doi:https://doi.org/10. 1016/B978-0-12-816132-6.00004-1.

Rodin, A., Branciamore, S., 2017. The universal genetic code and non-canonical variants, in: Reference Module in Life Sciences. Elsevier. URL: https:// WWW.sciencedirect.com/science/article/pii/B9780128096338073271, doi:https://doi.org/10.1016/B978-0-12-809633-8.07327-1.

Sanderson, H., Brown, R.S., Hania, P., McAllister, T.A., Majury, A., Liss, S.N., 2019. Chapter 7 - antimicrobial resistant genes and organisms as environmental contaminants of emerging concern: Addressing global public health risks, in: Roig, B., Weiss, K., Thireau, V. (Eds.), Management of Emerging Public Health Issues and Risks. Academic Press, pp. 147-187. URL: https://wWW.sciencedirect.com/ science/article/pii/B978012813290600007X, doi:https://doi.org/10. 1016/B978-0-12-813290-6.00007-X. 
Sauderson, N.S.R., Castro, M.G., Lowenstein, P.R., 2013. Chapter 29 - gene therapy: From theoretical potential to clinical implementation, in: Rimoin, D., Pyeritz, R., Korf, B. (Eds.), Emery and Rimoin's Principles and Practice of Medical Genetics. Academic Press, Oxford, pp. 1-32. URL: https://wWw.sciencedirect.com/ science/article/pii/B9780123838346000379, doi:https://doi.org/10. 1016/B978-0-12-383834-6.00037-9.

Schwela, D., Kotzias, D., 2005. Pollution, air indoor, in: Wexler, P. (Ed.), Encyclopedia of Toxicology (Second Edition). second edition ed.. Elsevier, New York, pp. 475-489. URL: https: //wWW.sciencedirect.com/science/article/pii/B0123694000007808, doi:https://doi.org/10.1016/B0-12-369400-0/00780-8.

Shen, C.H., 2019. Chapter 4 - gene expression: Translation of the genetic code, in: Shen, C.H. (Ed.), Diagnostic Molecular Biology. Academic Press, pp. 87-116. URL: https://wwW.sciencedirect.com/ science/article/pii/B9780128028230000043, doi:https://doi.org/10. 1016/B978-0-12-802823-0.00004-3.

Shore, S.N., 2003. Celestial mechanics, in: Meyers, R.A. (Ed.), Encyclopedia of Physical Science and Technology (Third Edition). third edition ed.. Academic Press, New York, pp. 527-540. URL: https: //WWW.sciencedirect.com/science/article/pii/B0122274105000880, doi:https://doi.org/10.1016/B0-12-227410-5/00088-0.

Shrestha, P.K., Panthi, K.K., 2015. Assessment of the effect of stress anisotropy on tunnel deformation in the kaligandaki project in the nepal himalaya. Bulletin of Engineering Geology and the Environment 74, 815826. URL: https://doi.org/10.1007/s10064-014-0641-5, doi:10.1007/ s10064-014-0641-5.

Speight, J.G., 2019. Chapter 12 - upgrading by solvent treatment, in: Speight, J.G. (Ed.), Heavy Oil Recovery and Upgrading. Gulf Profes- 
sional Publishing, pp. 529-558. URL: https://www.sciencedirect.com/ science/article/pii/B978012813025400012X, doi:https://doi.org/10. 1016/B978-0-12-813025-4.00012-X.

Stacy, J., Vestrand, W., 2003. Gamma-ray astronomy, in: Meyers, R.A. (Ed.), Encyclopedia of Physical Science and Technology (Third Edition). third edition ed.. Academic Press, New York, pp. 397-432. URL: https: //wWW.sciencedirect.com/science/article/pii/B012227410500274X, doi:https://doi.org/10.1016/B0-12-227410-5/00274-X.

Takala, T., 2012. Cloning, in: Chadwick, R. (Ed.), Encyclopedia of Applied Ethics (Second Edition). second edition ed.. Academic Press, San Diego, pp. 488-493. URL: https://wWw.sciencedirect.com/ science/article/pii/B9780123739322001733, doi:https://doi.org/10. 1016/B978-0-12-373932-2.00173-3.

Teegavarapu, R.S., 2019. Chapter 2 - changes and trends in precipitation extremes and characteristics: Links to climate variability and change, in: Teegavarapu, R. (Ed.), Trends and Changes in Hydroclimatic Variables. Elsevier, pp. 91-148. URL: https://wWW.sciencedirect.com/ science/article/pii/B9780128109854000025, doi:https://doi.org/10. 1016/B978-0-12-810985-4.00002-5.

Telfer, S., Woodburn, J., 2010. The use of 3d surface scanning for the measurement and assessment of the human foot. Journal of Foot and Ankle Research 3, 19. URL: https://doi.org/10.1186/1757-1146-3-19, doi:10.1186/1757-1146-3-19.

Tu, Y., Laaksonen, A., 2010. Chapter 1 - implementing quantum mechanics into molecular mechanicscombined $\mathrm{qm} / \mathrm{mm}$ modeling methods, in: Sabin, J.R., Brndas, E. (Eds.), Combining Quantum Mechanics and Molecular Mechanics. Some Recent Progresses in QM/MM Methods. Academic Press. volume 59 of Advances in Quantum Chemistry, pp. 1-15. URL: https://www.sciencedirect.com/science/article/ 

$59001-4$.

Vivian, C., Murray, L., 2009. Pollution, solids, in: Cochran, J.K., Bokuniewicz, H.J., Yager, P.L. (Eds.), Encyclopedia of Ocean Sciences (Third Edition). third edition ed.. Academic Press, Oxford, pp. 359-365. URL: https:// WWW.sciencedirect.com/science/article/pii/B9780128130810007679, doi:https://doi.org/10.1016/B978-0-12-813081-0.00767-9.

Wagner, N.J., Coertzen, M., Matjie, R., van Dyk, J., 2008. Chapter 5 - coal gasification, in: Surez-Ruiz, I., Crelling, J.C. (Eds.), Applied Coal Petrology. Elsevier, Burlington, pp. 119-144. URL: https://www.sciencedirect.com/ science/article/pii/B9780080450513000051, doi:https://doi.org/10. 1016/B978-0-08-045051-3.00005-1.

Wang, J.H., 2018. 23 - lifecycle cost and performance analysis for repair of concrete tunnels, in: Pacheco-Torgal, F., Melchers, R.E., Shi, X., Belie, N.D., Tittelboom, K.V., Sez, A. (Eds.), EcoEfficient Repair and Rehabilitation of Concrete Infrastructures. Woodhead Publishing. Woodhead Publishing Series in Civil and Structural Engineering, pp. 637-672. URL: https://wWW.sciencedirect.com/ science/article/pii/B978008102181100023X, doi:https://doi.org/10. 1016/B978-0-08-102181-1.00023-X.

840 Wang, Z., 2019. Chapter 4 - design of the concentration system, in: Wang, Z. (Ed.), Design of Solar Thermal Power Plants. Academic Press, pp. 225-318. URL: https://www.sciencedirect.com/ science/article/pii/B9780128156131000043, doi:https://doi.org/10. 1016/B978-0-12-815613-1.00004-3.

${ }_{845}$ Waseem, H., Saleem ur Rehman, H., Ali, J., Iqbal, M.J., Ali, M.I., 2020. Chapter 14 - global trends in args measured by ht-qpcr platforms, in: Hashmi, M.Z. (Ed.), Antibiotics and Antimicrobial Resistance Genes in 
the Environment. Elsevier. volume 1 of Advances in Environmental Pollution Research series, pp. 206-222. URL: https://wWw.sciencedirect.com/ science/article/pii/B9780128188828000140, doi:https://doi.org/10. 1016/B978-0-12-818882-8.00014-0.

Whitson, A.E., Kocher, L.M., Pollard, J., Nasarwanji, M., 2018. Method for measuring wear on boot outsoles using a 3d laser scanner. Footwear Science 10, 149-155. URL: https://doi.org/ 10.1080/19424280.2018.1486463, doi:10.1080/19424280.2018.1486463, arXiv:https://doi.org/10.1080/19424280.2018.1486463.

Wilson, C., Hargreaves, T., Hauxwell-Baldwin, R., 2017. Benefits and risks of smart home technologies. Energy Policy 103, 72-83. URL: https: //wWw.sciencedirect.com/science/article/pii/S030142151630711X, doi:https://doi.org/10.1016/j.enpol.2016.12.047.

Wilson, W., Lindstrom, E., Apel, J., 2009. Satellite oceanography, history, and introductory concepts, in: Steele, J.H. (Ed.), Encyclopedia of Ocean Sciences (Second Edition). second edition ed.. Academic Press, Oxford, pp. 65-79. URL: https://wWW.sciencedirect.com/ science/article/pii/B9780123744739007372, doi:https://doi.org/10. 1016/B978-012374473-9.00737-2.

Zhang, Y., 2019. Chapter five - fine particles characteristics of ultra-low emission coal-fired power plants, in: Zhang, Y., Wang, T., Pan, W.P., Romero, C.E. (Eds.), Advances in Ultra-Low Emission Control Technologies for Coal-Fired Power Plants. Woodhead Publishing. Woodhead Publishing Series in Energy, pp. 159-197. URL: https://wWw.sciencedirect.com/ science/article/pii/B978008102418800005X, doi:https://doi.org/10. 1016/B978-0-08-102418-8.00005-X.

Zhu, J., Aikawa, B., 2004. Determination of aniline and related mono875 aromatic amines in indoor air in selected canadian residences by a modified thermal desorption $\mathrm{gc} / \mathrm{ms}$ method. Environment International 
30, 135-143. URL: https://www.sciencedirect.com/science/article/ pii/S0160412003001685, doi:https://doi.org/10.1016/S0160-4120(03) $00168-5$.

880 alohar, J., 2018. Chapter 33 - predictability of volcanic eruptions, in: alohar, J. (Ed.), The Omega-Theory. Elsevier. volume 2 of Developments in Structural Geology and Tectonics, pp. 503-513. URL: https:// WWW.sciencedirect.com/science/article/pii/B9780128145807000332, doi:https://doi.org/10.1016/B978-0-12-814580-7.00033-2. 